B RONWYN H. HALL

University of California, Berkeley

National Bureau of Economic Research

\title{
Industrial Research during the 1980s: Did the Rate of Return Fall?
}

THIS PAPER IS MOTIVATED by two recent empirical findings about the returns to industrial research and development (R\&D) at the firm level. First, the stock market value of R\&D spending relative to ordinary capital investment in U.S. manufacturing firms fell precipitously during the 1980s. ${ }^{1}$ Second, the contribution of R\&D to productivity in these same firms apparently declined from an elasticity of about $0.10-0.15$ during the $1960 \mathrm{~s}$ and $1970 \mathrm{~s}^{2}$ to around 0.02 during the $1980 \mathrm{ss}^{3}$ Taken together, these findings suggest that something has happened to the marginal private rate of return to industrial $\mathrm{R} \& \mathrm{D}$ during the recent past. The question is, what? This paper explores these prior findings in greater detail in an effort to understand what factors are causing them and to ascertain the pervasiveness of this apparent decline in $\mathrm{R} \& \mathrm{D}$ productivity.

Three principal results emerged from this study. First, the observed decline in the value of $R \& D$ relative to ordinary physical capital is composed of two effects: an increase in the value of ordinary capital as firms

Thanks to Zvi Griliches, Robert Hall, Adam Jaffe, Jacques Mairesse, Edwin Mansfield, Richard Nelson, and the editors of this issue for many helpful discussions and comments on this work. I am grateful to the National Science Foundation and the Econometrics Laboratory, University of California at Berkeley, for support of the data preparation and estimation and to the Hoover Institution for its support and hospitality during the writing of this paper.

1. Hall (1993b).

2. Bureau of Labor Statistics (1989). This publication surveys a large number of previous studies of the private returns to R\&D; see also Mairesse and Sassenou (1991) and Lichtenberg and Siegel (1991).

3. Mairesse and Hall (1993). 
exited and the publicly traded manufacturing sector shrank during the corporate restructuring boom of the last decade, and a steep decline in the absolute value of $\mathrm{R} \& \mathrm{D}$ assets. Second, this decline was concentrated in several major manufacturing sectors: electrical, instruments, computing, and electronics. Third, although the contribution of R\&D investment to productivity growth was low during the 1970s and the first half of the 1980s, it revived in the second half in all sectors except electrical and large-scale computing, machinery, metals, and autos (the well-publicized corporate behemoths). In subsequent sections of this paper, these findings are reported in greater detail, and some explanations advanced.

The observed private rate of return to industrial $R \& D$ is the outcome of a complex interaction between the demand from enterprises for R\&D investment funds and the supply of these funds from investors. The location of the demand curve is influenced by such factors as expected final (consumer) demand and the transformation function that turns R\&D spending into innovative output ("technological opportunity"). The curve is downward sloping because not all R\&D projects have the same expected rate of return and the firm chooses those with the highest return first. The location of the supply curve (the funds available at any particular level of capital cost) is determined by the willingness of investors to supply funds to innovating firms (the required market rate of return), the rate at which the returns to the capital depreciate or the capital becomes obsolete, and the tax treatment of such investment. Under a variety of assumptions, the supply curve will slope upward. For example, asymmetric information between firms and investors implies that, to fund projects about which they do not have full information, investors will demand a "lemons" premium in the form of a higher rate of return. When firms undertake R\&D investment, they invest until the expected rate of return to such investment equals the cost of capital, that is, the point where the demand for R\&D funds equals the supply.

Therefore, the measured productivity of $R \& D$ investment is only loosely linked to the market value of such investment, which is based on expectations about many other factors that affect its cost, such as changes in its price, the rate of obsolescence, or the ability to capture the returns. In addition, finding that the gross rate of return to $R \& D$ investment has fallen is not necessarily bad news. In simple terms this finding implies either that the supply curve has shifted out, so firms face a cheaper schedule for the cost of funds, or that the demand curve has shifted inward. In 
the former case firms will actually perform more R\&D even though the rate of return has fallen, and this could be a desirable outcome for society. If the fall is due to a demand curve shift, either because consumer demand has temporarily diminished (a recession) or because R\&D has become less productive, the fall in return to $\mathrm{R} \& \mathrm{D}$ would be associated with a decline in $\mathrm{R} \& \mathrm{D}$ spending, other things equal.

If the world were static, interpretation of the apparent fall in the rate of return to $R \& D$ during the 1980 s would be simple, because the R\&D intensity of the publicly traded manufacturing sector and the manufacturing sector as a whole rose rather than fell. ${ }^{4}$ There is also some evidence that the relative cost of $\mathrm{R} \& \mathrm{D}$ funds to these firms was lower than in early periods, both because of the willingness of investors to buy technology stocks, at least in the first half of the period, and because an R\&D tax credit was available. ${ }^{5}$ Thus, the fall in the rate of return could be interpreted as arising from a shift outward in the supply curve of funds for R\&D. The static analysis leaves out a large part of the story, however. The decision to invest is made under considerable uncertainty, and firms do not really know what the underlying demand for the output of their $\mathrm{R} \& \mathrm{D}$ is, nor do they have much idea how productive the research will be. The realized rate of return may differ substantially from that which the firm contemplated at the time that it made the investment.

To make the preceding discussion more concrete, consider the stylized dynamic programming model of a firm that uses two kinds of capital productively to generate a stream of profits. (This model is presented in appendix A. $)^{6}$ Under the assumption that the firm chooses the level of ordinary and R\&D capital to maximize the present discounted value of the profits produced by that capital, the model yields the familiar result that the expected rate of return to each capital along the optimal investment path is just equal to the Jorgensonian cost of capital:

$$
E \Pi_{K}=p_{r}\left(\rho+\delta_{r}-\frac{\dot{p}_{r}}{p_{r}}\right),
$$

4. See figure 1 , which displays the aggregate $R \& D$-to-sales ratio for the publicly traded firms in manufacturing (the curves labeled CS) and for the sector as a whole (the curve labeled NSF). The former group of firms is the population from which the sample studied here is drawn.

5. Hall (1993a).

6. The model is a standard one in the investment literature; this particular version is based on the model of Hayashi and Inoue (1991). 
where $\rho$ is the investor's required rate of return (the rate at which the future cash flows or dividends are discounted), $\delta_{r}$ is the depreciation rate for $\mathrm{R} \& \mathrm{D}$ capital, and $p_{r}$ is the price of $\mathrm{R} \& \mathrm{D}$ relative to that of output (the dot denotes a time derivative). ${ }^{7}$

At the beginning of each period, the firm will attempt to choose R\&D investment so that the equality in equation 1 is maintained. If the marginal product schedule is downward sloping, a higher relative R\&D price, higher required rates of return, and higher depreciation rates (obsolescence rates) of $R \& D$ will lower $R \& D$ spending, while an expected increase in the future price of $R \& D$ will increase current spending.

Several things are already known about the values of parameters in the cost-of-capital formula. First, $p_{r}$, the relative price of $\mathrm{R} \& \mathrm{D}$, was about 5 to 10 percent lower during the 1980s than it was earlier because of the R\&D tax credit; this fact would be expected to reduce the required rate of return for $R \& D$ by the same amount. The frequent changes in the tax credit legislation have made the capital gain associated with $p_{r}$ fairly substantial in three of the years between 1980 and 1990: a gain of about 8 percent in 1981-82 as the tax credit began to take effect, and another gain of 10 percent in 1990 , when the credit was changed to a fixed, rather than a rolling, base.

Second, the investor's required rate of return, $\rho$, for these firms has been measured by Hall and Hall, who found that firms that performed R\&D during the last thirty years had required slightly lower rates of return than those firms with no $R \& D$, and that the effect of $R \& D$ investment on the rate used by the stock market to discount the firm's dividends was roughly the same as that of ordinary investment. ${ }^{8} \mathrm{We}$ measured a coefficient of -0.15 during the 1970 s and -0.20 during the 1980 s for a variable that was the ratio of $R \& D$ investment to assets. For a firm whose ratio of R\&D to assets is 5 percent (which is typical of R\&D-performing firms), the rate of return required by the stock market was 75 to 100 basis points lower than for non-R\&D firms. The total risk premium for these firms was around 1-2 percent during the 1980s and somewhat higher during the earlier periods. Combining these results with an estimate of the risk-free rate from three-year Treasury

7. This relative price will be after tax, that is, it will include the implicit tax subsidy to $R \& D$ in the numerator and the effect of corporate profits taxes in the denominator.

8. Hall and Hall (1993). 
Figure 1. Aggregate R\&D-to-Sales Ratio, U.S. Manufacturing Sector, 1971-90

Percent

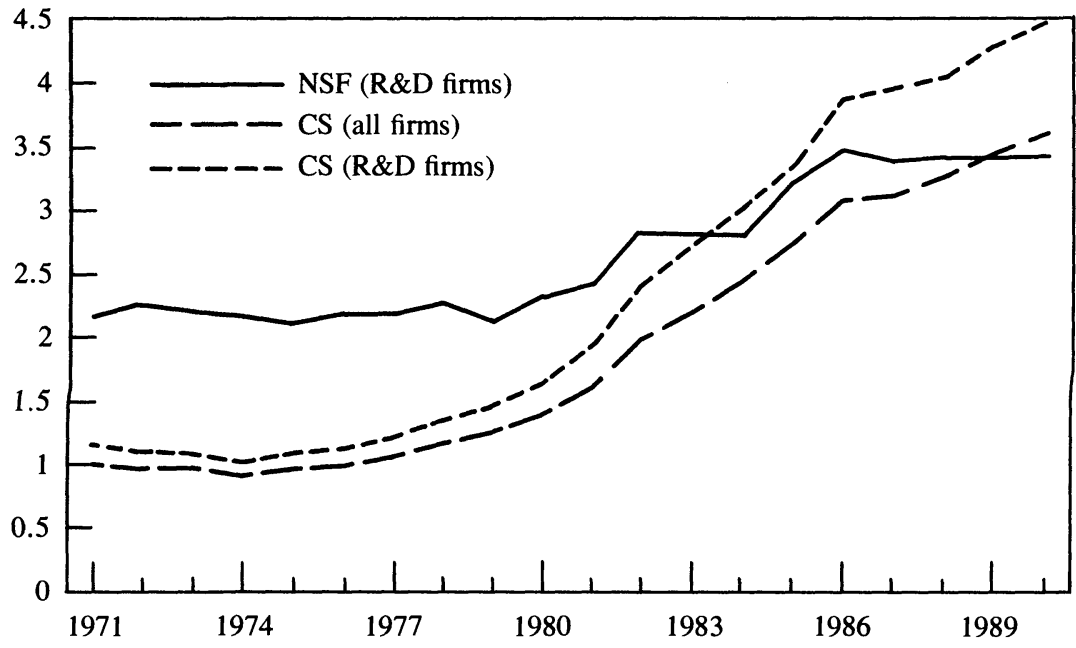

Source: Author's calculations for CS; National Science Foundation (1991) for NSF.

bonds, we estimated total required rates of return for the shares of R\&Dperforming firms at 6.3 percent during the 1960 s, 9.0 percent during the 1970 s, 10.7 percent during $1981-85$, and 8.6 percent during $1986-$ $90 .{ }^{9}$

Putting these numbers together with an assumed depreciation rate for R\&D capital of 15 percent yields very rough estimates for the cost of R\&D capital of 0.21 in the 1960 s, 0.24 in the 1970 s, 0.26 in the first half of the 1980s, and 0.24 in the second half. ${ }^{10}$ Thus, there is some evidence that the relative cost of R\&D fell slightly during the 1980 s, but the numbers seem too close together to account for the large increase in $\mathrm{R} \& \mathrm{D}$ shown in figure 1 . Therefore, it is likely that the $E\left[\Pi_{K}\right]$ schedule (that is, the marginal product of $R \& D$ as a function of the level of $R \& D$ investment, which in turn generates the demand for $R \& D$ investment) also shifted out during the early 1980 s.

9. The numbers for the two separate five-year periods in the 1980 s are not reported in Hall and Hall (1993) but have been newly estimated for this paper.

10. These estimates are made without considering adjustment costs, which may be considerable for R\&D but have proved difficult to estimate reliably (Hall and Hayashi 1988; Himmelberg and Petersen 1991). Adjustment costs would raise the cost of capital overall, but this correction is not likely to differ substantially across the periods. 
Equation 1 expresses the condition under which firms make their investment decisions, but as appendix A shows, it also plays an important role in determining the market's valuation of R\&D investment. After the investment has been undertaken, the ex-post gap between the marginal product of the capital $\Pi_{K}$ and the current cost of that capital is an indicator of the rents or excess returns from the capital; it is this gap that will be capitalized into the market value of the assets corresponding to this kind of capital. A finding that these rents have fallen or are negative implies either that the realized marginal product was much lower than was expected or that the cost of future investments has risen.

The goal of this paper is to distinguish among these explanations for the fall in the market value of $R \& D$ investment. Having eliminated at the outset the possibility that the entire effect is driven by changes in the relative price of $R \& D$ or in the required rate of return to $R \& D$ assets, I focus on the two other components of equation 1: the expected and actual marginal product of R\&D capital, and the rate of depreciation or obsolescence of such capital. To measure the former, conventional $\mathrm{R} \& \mathrm{D}$ productivity regressions are used; these are interesting per se because of their relation to previous work that does not include this time period. ${ }^{11}$ Measuring the latter is somewhat more difficult; the evidence that the rate of obsolescence has risen in some sectors in recent years is based on distinctions between the market value of "old" R\&D assets and incremental new $R \& D$ above and beyond that necessary to maintain the assets as well as on anecdotal evidence about the industries.

The paper begins by reviewing the aggregate trends in R\&D spending in manufacturing. The first section sets the stage for the subsequent sections by highlighting major changes in the composition of the publicly traded manufacturing sector during the 1980s, particularly the increasing R\&D intensity of the sector as less technology-oriented firms and divisions exited by means of private buyout. The next section reviews in substantially greater detail earlier evidence I gathered on market value ${ }^{12}$ and suggests that equity market values at the beginning of the 1980s strongly signaled (or forced) the type of restructuring that

11. See Mairesse and Sassenou (1991) for a survey of previous estimates of the relationship between productivity and $R \& D$.

12. Hall (1993b, 1993c). 
took place during the period. This section then measures and evaluates changes in the valuation of old and new R\&D capital across various industrial sectors, in an effort to draw some conclusions about the depreciation of returns to this capital.

The last major sections of the paper present evidence on the output (or marginal product) of industrial R\&D. Commonly used measures of output include patent counts, innovation counts, and the profitability or productivity of the firms undertaking investment. With the exception of innovation counts, for which data are not readily available during the relevant period, the available evidence suggests that these measures of innovation output per unit of input declined during the 1980s for U.S. manufacturing firms, although there is some evidence that the decline was arrested toward the end of the period.$^{13}$ I focus here on a major indicator of technological success: the contribution of R\&D investment to productivity and sales growth at the firm level. Because good patent and innovation data are unavailable at the firm level, I defer the examination of these measures to future work by others. The paper concludes by combining the evidence on realized returns and costs of R\&D during the 1980 s into a coherent, but somewhat speculative, story.

\section{The Shrinking Manufacturing Sector?}

Figure 1 presents the basic facts about recent trends in the $R \& D$ intensity of manufacturing. The figure reveals a puzzle in the data that underlies some of the contradictory rhetoric on the rise or fall of industrial R\&D during the 1980s. The puzzle concerns the aggregate R\&D intensity of manufacturing in the United States. Data based on the National Science Foundation survey of industrial R\&D show that the

13. It is well known that the patent yield per industrial $R \& D$ dollar has been declining since at least the beginning of the sample period here (Griliches 1989). Work by the present author (not shown) confirms that the decline continues through at least 1990 but at a somewhat lower rate. Caballero and Jaffe (1993) find that although there has been a long-run decline in patent yield, it began to rise again after about 1986 when the date of patent application is used (rather than the grant date). A sample of about eighty of the largest firms considered here for which we do have individual patenting numbers for 1987 and 1991 (Business Week 1992) shows the same decline in patenting yield throughout the 1980 s as the aggregate data do. 
ratio of $R \& D$ to sales of manufacturing firms was stagnant at about 2.2 percent during the 1970 s, rose to about 3.4 percent by 1986 , and since then has been stagnant at about 3.4 percent. In contrast, the R\&D intensity measure for the Compustat sample of firms (which is essentially all manufacturing firms whose stock is publicly traded) has risen continuously since the mid-1970s, from 1.0 percent to 4.5 percent in $1990 .{ }^{14}$

Appendix B investigates the source of the discrepancy between the Compustat and NSF numbers in more detail and reaches the conclusion that the differences occur because the publicly traded manufacturing sector shrank substantially during the 1980 s, but that the decline in size came primarily from the loss of firms that were not R\&D-intensive. Using the results of other research on the restructuring of the corporate sector during the 1980 s, it is possible to advance a couple of more detailed explanations of this phenomenon.

First, one cause of the shift in R\&D intensity in the Compustat data may be the increasing focus of these manufacturing firms on their core businesses. ${ }^{15}$ Such a refocusing would mean that manufacturing firms have a larger share of their assets actually in manufacturing and that the resulting (smaller) firms would be more R\&D-intensive, because manufacturing as a whole tends to perform the vast bulk of R\&D. Because of variability in the sampling frame from which the NSF R\&D survey is drawn, these changes may not affect the NSF number in the same way. ${ }^{16}$

14. $R \& D$ intensity in figure 1 is measured in the usual way: the nominal ratio of R\&D spending to sales. The two ratios shown for Compustat are for all firms in the file and for only those firms that perform R\&D, while that for NSF is the ratio of manufacturing $R \& D$ spending to the total sales of the firms in the sample. Both sets of numbers exclude foreign-owned and nonmanufacturing firms but include R\&D performed by domestic firms in foreign establishments. In principle, the higher of the two Compustat curves should be directly comparable to the NSF numbers, because it includes only firms that perform R\&D. See National Science Foundation (1985, 1991); Standard and Poor (1991 and earlier editions).

15. For example, see Bhagat, Shleifer, and Vishny (1990) for evidence that sixtytwo large hostile takeover contests between 1984 and 1986 resulted in the reallocation of corporate assets to firms in the same industries as those assets.

16. Until very recently, the economic censuses have not covered the service sector adequately; the R\&D survey sample is primarily drawn from these censuses, which are establishment-based, although the survey itself is addressed to enterprises. Thus, there is a question, not really answerable using public data, as to how quickly the NSF itself can adapt to the changes in the structure of the manufacturing sector. 
Table 1. Exit from the Publicly Traded Manufacturing Sector:

Weighted R\&D-to-Sales Ratio

Percent

\begin{tabular}{lcccc}
\hline & \multirow{2}{*}{$\begin{array}{c}\text { Went } \\
\text { Period }\end{array}$} & $\begin{array}{c}\text { Foreign } \\
\text { acquisition }\end{array}$ & Nonexiting firms \\
\cline { 4 - 5 } & 0.43 & 1.35 & 1.18 & R\&D-doers \\
$1976-80$ & 0.55 & 1.21 & 2.19 & 1.81 \\
$1981-85$ & 1.27 & 2.91 & 3.31 & 2.67 \\
$1986-90$ & & & 4.14 \\
\hline
\end{tabular}

Source: Author's calculations.

A second factor influencing the composition of the manufacturing sector was the nature of entry into the publicly traded sector during the 1980s. Most of the new entrants were high-technology firms traded over the counter using the NASDAQ system, and these firms are likely to be relatively more $R \& D$-intensive. As I show later in the paper, at the beginning of the 1980 s the equity market placed a high value on R\&D assets, which appears to have encouraged entry into the sector. At the same time the wave of leveraged buyouts (LBOs) and "going private" restructurings affected non-R\&D-intensive firms disproportionately. In $1991 \mathrm{I}$ reported that the total R\&D per employee for Compustat firms in 1982 was $\$ 2.1$ million, whereas the R\&D per employee for the firms that exited through private buyouts between 1977 and 1987 was only $\$ 500,000 .{ }^{17}$ Lichtenberg and Siegel have a similar finding for complete-firm LBOs that took place between 1983 and 1986: the R\&D-to-sales ratio for non-LBO firms in their large Census of Manufactures sample is 3.5 percent, while that for the LBO firms is 1.0 percent. ${ }^{18}$ Using a multiple regression approach, Blair and Schary controlled for such variables as cash flow variance, returns to capital, asset growth, and lagged cash flow, and found that the ratio of $R \& D$ to sales is a significant predictor of exit via a private buyout. ${ }^{19}$ Table 1 updates my earlier results through 1990, displaying the sales-weighted R\&D intensity for firms that did and did not exit during each of the three five-year periods between 1976 and 1990. Note that although the R\&D intensity of exiting firms rose in the last period, the differential relative to those that did not exit remained the same.

17. Hall (1991).

18. Lichtenberg and Siegel (1990).

19. Blair and Schary (1993). 
The exit of publicly traded manufacturing firms documented in appendix B is only part of the story, however. Many other "going private" transactions and foreign acquisitions took place at the division level, and these tended to have the same character as the whole-company transactions. Thus, R\&D intensity of these transactions was probably also low, and the remaining publicly traded firms probably had a higher ratio of $R \& D$ to sales. Overall, the "deal" decade and what Jensen calls the "modern industrial revolution" moved a substantial part of corporate assets out of the publicly traded sector. ${ }^{20}$ These assets, however, were primarily in mature industries that were downsizing in response to excess capacity and foreign competition; they were not in the high-technology and fast-growing sectors where R\&D investment was important.

\section{The Stock Market Valuation of R\&D Investment}

The equity markets forecast these changes quite well at the beginning of the decade, but adjustment to these market signals was very slow. In two other papers published in 1993, I presented evidence that the stock market valuation of $R \& D$ investment relative to ordinary investment fell rather precipitously during the $1980 \mathrm{ss}^{21}$ This was true both for current R\&D spending and for a stock variable constructed from the past history of R\&D spending. This fact by itself suggests either a onetime write-off of past $R \& D$ investments by the market or a substantial fall in the rate of return to $R \& D$ spending during the period. Such a fall could have been induced by a decrease either in the cost of funds (a supply shift) or in the derived demand for R\&D investment caused by reduced demand for the innovation it generates, or by diminishing returns to innovation. Before investigating these possibilities, I explore the finding more thoroughly in an effort to narrow the search for explanations. The explorations reported here are the following: a search for robust econometric specification, separation of the relative valuation estimate into changes in the value of capital (the denominator) and changes in the value of R\&D (the numerator), and an industry-level set of estimates.

20. Jensen (1993).

21. Hall (1993b, 1993c). 
The framework I used to explore the valuation of R\&D assets was a simple hedonic regression originally proposed by Griliches: ${ }^{22}$

$$
\log V_{i t} / A_{i t}=\log Q_{i t}=\log q_{t}+\frac{\gamma_{t}}{q_{t}} \frac{K_{i t}}{A_{i t}}+\epsilon_{i t},
$$

where $V_{i t}$ is the total market value (debt plus equity) of the firm, $A_{i t}$ is the book value of the physical assets, and $K_{i t}$ is the R\&D "capital," constructed from the past history of R\&D spending in the firm. ${ }^{23}$ The coefficients estimated are $q_{t}$, the market's valuation of book assets (Tobin's $Q$ ), and $\left(\gamma_{t} / q_{t}\right)$, the valuation of $\mathrm{R} \& \mathrm{D}$ assets relative to ordinary assets. Both coefficients were allowed to vary over time to reflect the fact that market premiums may (and do) change with the state of the economy. Equation 2 is derived from a very simple model of market valuation where the stocks are additive in value:

$$
V_{i t}=q_{t} A_{i t}+\gamma_{t} K_{i t}+V_{i t}
$$

Equation 3 is transformed to the logarithmic form in equation 2 because the extreme heteroskedasticity of $V_{i t}$ makes estimates of equation 3 unstable and inefficient. The logarithmic approximation is justified because $R \& D$ capital is typically much smaller than ordinary capital, at least in the large manufacturing firms normally studied.

As firms have become more R\&D-intensive, however, and smaller high-technology firms have entered the sample, the logarithmic approximation becomes harder and harder to justify and more and more sensitive to outliers in the variables on the right-hand side. Therefore, specification experiments (such as testing for heteroskedasticity and examining influential outliers) were performed using equations 2,3 , and a third alternative:

$$
\left(V_{i t} / A_{i t}\right)=Q_{i t}=q_{t}+\gamma_{t} \frac{K_{i t}}{A_{i t}}+\omega_{i t} .
$$

Estimates based on equation 4 but using robust estimation methods, least absolute deviations (LAD) estimation, were preferred, and therefore all estimates reported in this section are of this type. They are

22. Hall (1993b, 1993c); Griliches (1981).

23. A declining balance formula with a depreciation rate of 15 percent is used, to be consistent with previous work using this constructed capital. See Hall (1990) for details. 
more robust than those based on equations 2 and 3 and have the advantage that the R\&D valuation coefficient is a direct estimate of the absolute market value of $R \& D$, rather than a relative value.

Because the focus here is on the productivity of $R \& D$ and on the comparison of results for the 1980s with those from earlier periods, the sample of firms used to estimate the regression in equation 4 and throughout this paper differs somewhat from that I used in the two earlier 1993 papers. ${ }^{24}$ First, three groups of firms have been excluded: firms with foreign ownership that are listed on one of the U.S. exchanges (about 100 firms), nonmanufacturing firms (a few that appeared in the sample because they were in the original sample of firms reporting R\&D; see appendix B for details), and firms in the aircraft and aerospace sector (about 340 firms in SIC 372 and 376). These latter firms are those most affected by defense-related government $R \& D$, which is expected to have quite a different effect from privately funded R\&D on productivity and profitability. ${ }^{25}$ Second, I have extended the panel back to 1959 and included all the information in the original Griliches-Mairesse sample but have restricted it to include only firms that perform R\&D. ${ }^{26}$ This presents no serious sample selectivity problem after about 1974 (see appendix B), but before then only a fraction of firms that perform $R \& D$ actually reported their $R \& D$ expenditure publicly. I have verified that the sample change does not affect the results shown in figure 1 appreciably except in the very early years (up until 1973). More to the point, including only those firms that perform R\&D makes little difference to the estimated coefficients in the later periods.

Figure 2 reports the basic result of estimating equation 4 in two ways, one using R\&D capital and one using R\&D spending as a proxy for $R \& D$ capital. ${ }^{27}$ If the $R \& D$ spending variable is capitalized at six

24. Hall (1993b, 1993c).

25. See Griliches (1980a, 1986) and Lichtenberg and Siegel (1991) for evidence that this is the case. In principle, the Compustat $R \& D$ numbers that I am using do not include government-funded $R \& D$, so my results should not be biased when these firms are included, but reporting error is inevitable, and there are also conceptual difficulties in attempting to separate the roles of the two kinds of $R \& D$ in the performance of these firms.

26. Griliches and Mairesse (1984).

27. The figure shows a set of estimates for $q_{t}$ and $\gamma_{t}$ based on year-by-year regressions of the form shown in equation 3. Although there are separate estimates for $q_{t}$ from the two different specifications (one using the R\&D spending and the other, the R\&D stock), 
Figure 2. Market Valuation of Corporate Assets in the U.S. Manufacturing Sector, R\&D Firms, 1971-90

Capital coefficients

R\&D flow coefficient

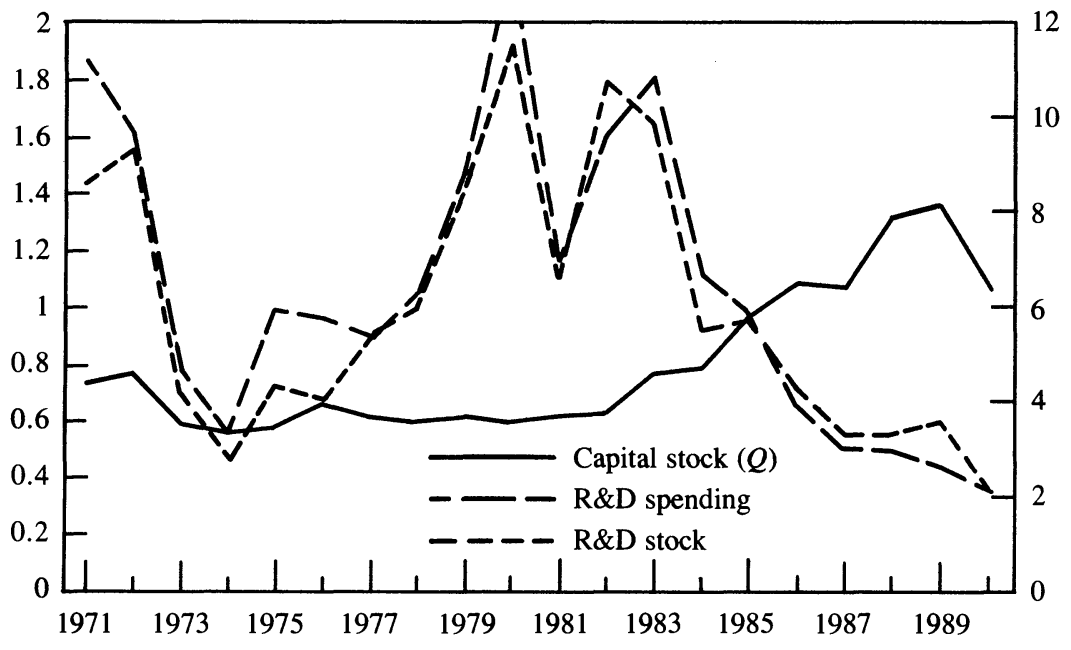

Source: Author's calculations.

times the flow (note the relative scales on the figure), the results are remarkably close, no matter which variable is used in the regression. This reflects the high correlation between $R \& D$ stock and flow in the cross section; as I will show later, this high correlation makes it extremely difficult to identify valuation separately for "new" and "old", R\&D.

The substantive result in figure 2 is the decomposition of the decline in the relative valuation of $R \& D$ assets during the 1980 s into two components: a doubling of the value of ordinary assets from a $Q$ of 0.6 at the beginning of the 1980 s to around 1.2 at the end, and a decrease in the value of $R \& D$ assets from approximately 1.5 to about 0.4 (a factor of more than three). Although the R\&D coefficients are imprecisely estimated and fluctuate a great deal, the underlying message of the figure is too large in magnitude and too consistent over the last few years to be ignored.

In view of the discussion of restructuring and exit in the last section,

these are so close together that I have shown only one on the figure, that for the R\&D stock equation. 
figure 2 has a fairly clear interpretation. Throughout the 1970s the equity markets were signaling that manufacturing had an excess (or the wrong kind of) capacity, with a ratio of market to book value of about 0.6. This took a remarkably long time to correct itself, and not until the restructuring wave of the mid-1980s did $Q$ begin to rise toward unity, possibly overshooting at the end of the period. The sustained period during which the market value of the assets was below book value lends credence to those who have critiqued the operation of corporate governance systems during the recent past. ${ }^{28}$

During this same period, the equity markets were also signaling rather strongly that firms were underinvesting in R\&D assets, with a coefficient above unity between the end of 1978 and the end of 1985 . Although it took time to bring the market price of $R \& D$ assets down, firms began to respond to these signals almost immediately. The rate of change of R\&D intensity began to accelerate about 1979 (see figure 1). Since $1986 \mathrm{R} \& D$ intensity has continued to increase, but at a slower rate, and the value of $R \& D$ assets has fallen steeply, to a level of about 0.4 . This raises two questions: first, was the market right in the early 1980s that R\&D investment would yield supranormal returns, and second, if so, should the current discount be viewed with alarm? The next section tries to answer these questions with a look at the actual productivity of this R\&D investment.

To investigate these basic findings more thoroughly, the firms were divided into six broad technology sectors: chemical-based (chemicals, oil, and rubber and plastics), ${ }^{29}$ pharmaceuticals and medical instruments, ${ }^{30}$ electrical (electrical equipment and scientific instruments), ${ }^{31}$ computers (computing equipment and electronics) ${ }^{32}$ machinery (metals, machinery, autos, and engines), ${ }^{33}$ and a miscellaneous category (food, textiles, and apparel; lumber and wood; paper and printing; stone, clay, and glass; and miscellaneous manufacturing). ${ }^{34}$ Figure 3 summarizes the estimates for the six sectors in the same format as Figure 2. Despite

28. See, for example, Allen (1992), Black (1992, forthcoming), Grundfest (1993), and Jensen (1991, 1993).

29. SIC 28 excluding 283 and 284; SIC 29 and 30.

30. SIC 283, 284, and 384 .

31. SIC 36 excluding 365-367, and 38 excluding 384.

32. SIC 357, 365-367.

33. SIC 33-35 excluding 357; 37 excluding 372 and 376.

34. SIC 20-27, 31, 32, 39. 
Figure 3. Valuation of Corporate Assets by Industrial Sector, 1971-90

A. Chemicals, oil, and rubber

Ratio

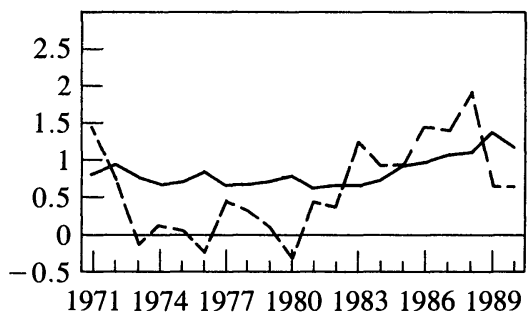

C. Electrical and instruments

Ratio

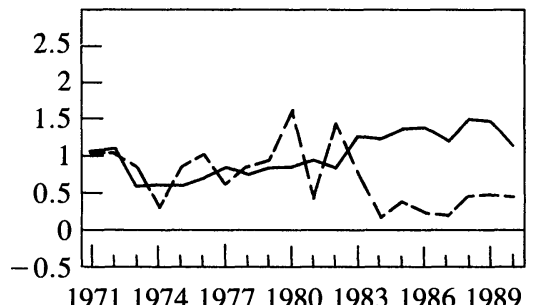

E. Metals, machinery, and autos

Ratio

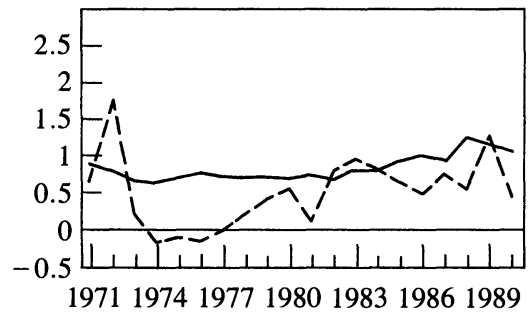

Capital stock
B. Pharmaceuticals

Ratio

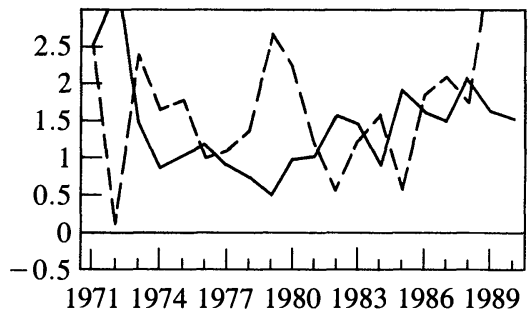

D. Computers and electronics

Ratio

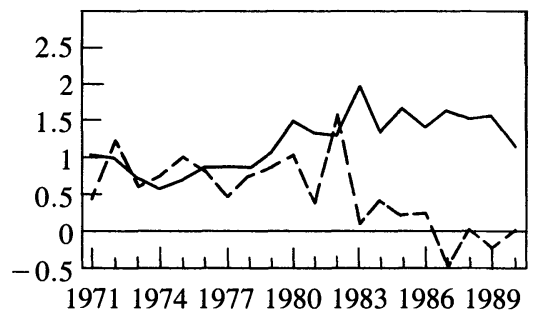

Ratio

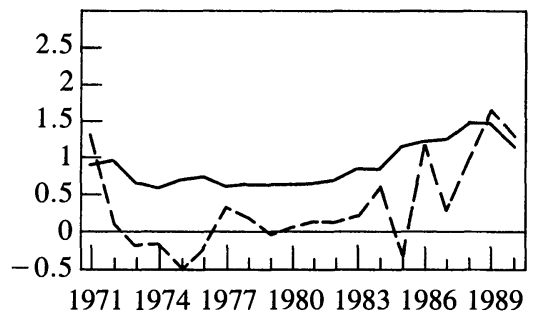

- - R\&D capital

Source: Author's estimated ratio of market to book value; see text. 
considerable noise in the estimates, which is characteristic of estimates based on stock market prices, the figure shows several interesting findings.

First, although timing varies slightly, Tobin's $Q$ for all the sectors rose from a discount in the mid-1970s to values slightly above unity by the end of the 1980s. Adjustment seems to have come slightly more quickly in the high-technology sectors of electrical and computing (and possibly pharmaceuticals). Second, the valuation of $R \& D$ assets rose in chemicals, machinery, and miscellaneous industries, from a low of around zero in the mid-1970s to parity with ordinary assets by the end of the period. These sectors are Chandler's "stable" and "low"' technology sectors, ${ }^{35}$ which were subject to so much restructuring pressure during the 1980s. They are the same industries where the restructuring activity between 1978 and 1987 affected firms that had some R\&D investment. ${ }^{36}$ Finally, the high-technology sectors show contrasting results. In pharmaceuticals the value of $R \& D$ assets remained above unity throughout most of the twenty years between 1971 and 1990, although it fluctuated greatly when a wave of biotechnology firms entered the sector. In contrast, the value of R\&D assets in the electrical and computing sectors fell rather suddenly between 1982 and 1984, from parity with ordinary assets to a very substantial discount (about 80 percent in the electrical sector and 100 percent in the computing sector).

Thus, the trends shown in figure 2 result from a combination of factors: general excess capacity to which the high-technology sectors adjusted more quickly than elsewhere, coupled with a demand for more R\&D investment in these sectors and less in the traditional manufacturing sectors. By the end of the period, a kind of equilibrium seems to have been reached, with the very important exception of the electrical and computing sectors, where R\&D assets are nearly worthless. The finding that motivated the investigation here seems, in fact, to be confined to these sectors.

\section{Increase in Obsolescence or Decline in Marginal Product?}

A central problem in analyzing the time pattern of returns to $R \& D$ has always been the fact that $R \& D$ investment at the firm level is a very

35. Chandler (forthcoming).

36. Hall (1991). 
smooth series relative to other firm-level variables such as sales, employment, and ordinary investment. ${ }^{37}$ This fact makes it difficult to estimate depreciation or obsolescence rates for $\mathrm{R} \& \mathrm{D}$ capital, let alone changes in those depreciation rates over time. The work reported here is no exception: an ad hoc decomposition of R\&D capital into "old" $R \& D$ and incremental "new" $R \& D$ is made, and these variables are entered into a market value equation to see if they are priced differently over time and in different industries. The conclusions drawn are necessarily qualitative because it is not possible to estimate a detailed model that would actually identify the varying depreciation rates. Even the coarse estimation results presented here are not without interest, however, and they do help in interpreting the recent changes in industrial $R \& D$ performance.

In appendix $\mathrm{A}$, an expression for the ratio of the market value of a dynamic profit-maximizing firm to the book value of its tangible assets (Tobin's $Q$ ) is derived using the methods of Hayashi and Inoue. ${ }^{38}$ Under various assumptions discussed in the appendix, this equation can be written

$$
\begin{aligned}
& Q_{i t} \sim \frac{P V_{t}\left(\text { rents from future } I_{i}\right)}{A_{i t}} \\
& \qquad+\frac{P V_{t}\left(\text { rents from future } R_{i}\right)}{A_{i t}}+\left(\frac{\pi_{R}}{\rho+\delta_{R}}\right) \frac{K_{i t}}{A_{i t}},
\end{aligned}
$$

where $i$ denotes firms, $t$ denotes years, and $P V_{t}(\cdot)$ is the present discounted value at time $t .{ }^{39} \pi_{R}$ is the marginal product of R\&D capital, and $\delta_{R}$ is the rate of depreciation of the private returns to R\&D. The $K / A$ term enters because of the failure to account for the value of the intangible technological assets in the book value of firm $i$; note that if $K_{i t}$ is properly measured and equation 1 holds, its coefficient in a regression based on equation 3 will be unity. A finding that the coefficient is

37. See Hall, Griliches, and Hausman (1986) for evidence on this point, and Hall (1992) for a comparison of ordinary investment to R\&D investment.

38. Hayashi and Inoue (1991).

39. I have suppressed the capital prices in this presentation, because the variables themselves will be measured in current dollars. A full development with prices is shown in appendix $\mathrm{A}$. 
less than unity implies either that $\pi_{r}$ is lower than expected at the time of investment or that $\delta_{r}$ is higher. ${ }^{40}$

The estimation problem is to find suitable proxies for the present discounted value of the rents from ordinary and R\&D capital. Under the assumption that the cross-section regression for Tobin's $Q$ represents some kind of steady state where the average future returns to past capital investments are roughly equal to cost, the natural proxies are the incremental increase in investment above and beyond that required to maintain the current capital stock: $I_{i t}-\delta_{I} A_{i, t-1}$ and $R_{i t}-\delta_{R} K_{i, t-1} \cdot^{41}$

Therefore, the stock of $\mathrm{R} \& \mathrm{D}$ is decomposed into two components: the ratio of net new $\mathrm{R} \& \mathrm{D}$ investment $\left(R-\delta K_{-1}\right)$ to assets, and the ratio of the previous year's stock of $\mathrm{R} \& \mathrm{D}\left(K_{-1}\right)$ to current assets. This decomposition is made to separate two effects that may contribute to the observed fall in the market value of $R \& D$ capital: first, past $R \& D$ may have become less valuable, and, second, net new R\&D may not be expected to yield returns. Both of the variables are included in yearby-year regressions of the following form:

$$
\begin{aligned}
Q_{i t}=\text { intercept }+ & \beta_{1 t} \frac{\left(I_{i t}-\delta_{I} A_{i, t-1}\right)}{A_{i t}} \\
& +\beta_{2 t} \frac{\left(R_{i t}-\delta_{R} K_{i, t-1}\right)}{A_{i t}}+\beta_{3 t} \frac{K_{i, t-1}}{A_{i t}} .
\end{aligned}
$$

The depreciation rate $\delta_{R}$ is set equal to 0.15 , which is the value used to

40. In practice, interpretation is not quite this simple, since $K$ itself is constructed using an assumed depreciation rate that may be counterfactual. However, because the depreciation rate is changing over time (possibly slowly) and R\&D is typically growing, the effect of the measurement error in $K$ will be somewhat mitigated. If $K$ were systematically overestimated because the true depreciation rate is higher, the coefficients reported here would be biased upward, and the true decline in the coefficient of $K$ in this regression during the 1980 s would be even greater.

41. Cockburn and Griliches (1988) used this decomposition for R\&D capital in a study based on a cross section of the same firms in 1980. They obtained results that were similar, but with lower coefficients, possibly because they also included two-digit industry dummies and patents stocks in the regression. Hall (1993c) finds that industry dummies tend to lower the flow coefficient by about 30 percent and the stock coefficient by more than 50 percent, which is consistent with the Cockburn and Griliches results. However, the dummies do not affect the decline in the R\&D coefficients during the 1980 s very much. Because part of the variation across industries in valuation is due to R\&D performance, it seemed appropriate here to focus on cross-industry comparison rather than simply removing industry effects. 
Figure 4. Market Valuation of R\&D Assets, U.S. Manufacturing, R\&D Firms, 1972-90

Flow coefficient

Stock coefficient

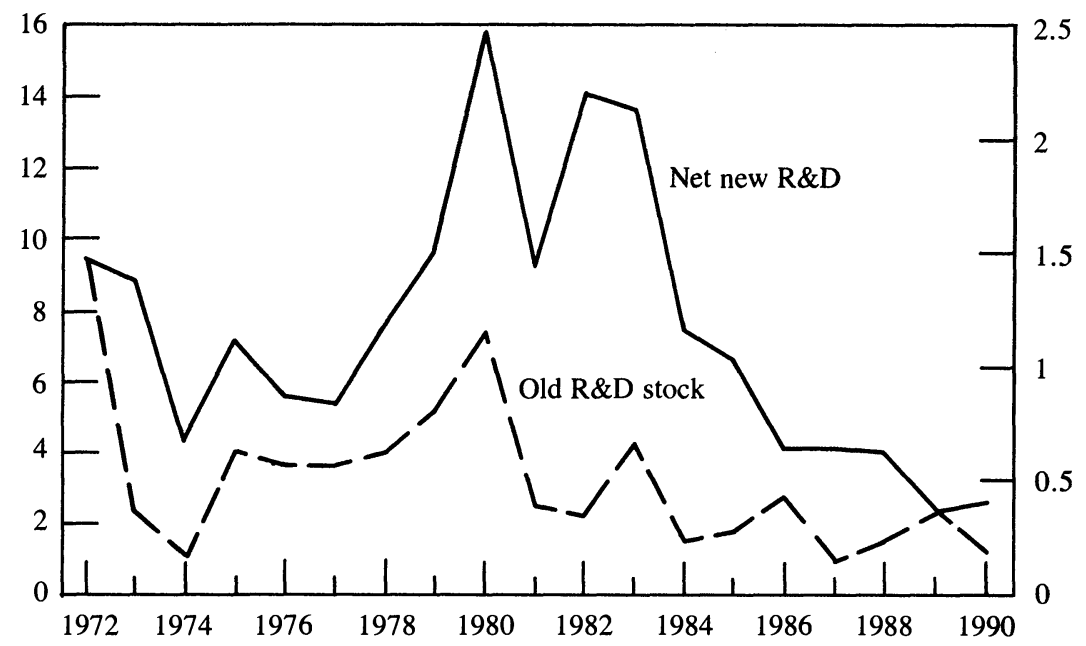

Source: See text.

construct the stock variable $K$, and the depreciation rate of ordinary capital $\delta_{I}$ is set to 0.10 . Other variables, such as cash flow to assets, sales growth to assets, and advertising to assets, can be included in this regression without changing the results reported here very much.

The estimated values of $\beta_{2 t}$ and $\beta_{3 t}$ for equation 6 are plotted in figure 4. Note the two scales, which have been chosen so that the flow of new $\mathrm{R} \& \mathrm{D}$ is capitalized at the rate implied by figure 2 (approximately 6.4). This figure clarifies somewhat an earlier finding. ${ }^{42}$ The gap between the value of incremental new $R \& D$ and old $R \& D$ capital is wider than when the flow and stock are considered separately, and the stock has explanatory power beyond that from its correlation with the flow. In a steadystate equilibrium and if the actual private depreciation rate of $R \& D$ capital were equal to 0.15 , both coefficients would be expected to be unity (after adjusting for the capitalization rate). In fact, both parts of this assumption fail: although the stock coefficient begins near 1 (with substantial fluctuation around the oil price shock) in the early 1970s, it falls to around 0.3 by the end of the period, which implies depreciation

42. Hall (1993b). 
rates much higher than 15 percent. The coefficient for incremental, or net new, $R \& D$ is much bigger than 1 , as it would be if the typical $R \& D$ firm is growing rather than in a steady state, and falls to slightly above 1 by the end of the period. The implied "cap" rate for the incremental investments falls from around 10 to 2 . The overall message is still the same as in the earlier papers: by the late 1980 s, both old and new R\&D are valued at about one quarter of what they were worth in the 1970s.

When the firms are divided into the very aggregated technology sectors of figure 3 , the estimates (not shown) become quite imprecise, but some patterns begin to emerge. First, the pharmaceutical industry is unique among the sectors, in that the value of both new and old R\&D declined very little during the entire period, although it fluctuated substantially, particularly with the emergence of the biotechnology industry in the mid-1980s.

Second, chemicals, machinery, and the miscellaneous industries all showed a tendency for the value of old $R \& D$ assets to rise from zero in the 1970 s to slightly below 1 by the end of the 1980 s. That increase agrees with the restructuring evidence that these were the sectors where firms were under pressure to shrink their $R \& D$ assets. The value of incremental new R\&D spending fluctuates greatly throughout the two decades, ending up higher overall in chemicals and lower in the other two sectors, but with no clear evidence of a time trend in any of these sectors.

Finally, the decline in the value of R\&D assets in the electrical and computing sectors is a combination of zero valuation on old R\&D capital since around 1980, and a continuous decline in the value of new investment, which began at the same time. The decline was earlier and steeper in the electrical sector and quite sudden (in 1984) in the computing sector.

It is hard to escape the conclusion that the differing nature of the competitive challenges in these sectors may have something to do with the apparent differences in the returns to R\&D. The electrical and computing sectors have been subject to considerably more entry and competition (much of it of the lower-cost foreign variety) than the chemical and pharmaceutical sectors, and this seems to have been reflected in more rapid write-offs of the intangible assets created by R\&D investment. In the electrical and particularly computing sectors, product cycles have speeded up, giving less time to reap the returns to $R \& D$, 
and imitation has in some cases been quite successful and fairly immediate, increasing the private rate of obsolescence. Even the entry of domestic firms into these sectors has been sizable during the period. In 1980 firms in these sectors made up 21 percent of all publicly traded manufacturing firms (27 percent in terms of employment). By 1990 they made up 28 percent of the whole sector and 35 percent in terms of employment.

In contrast the $R \& D$ capital in the pharmaceuticals industry seems to have been expected to yield profits on a par with its cost throughout the period, perhaps because this is the one industry where intellectual property protection is highly successful. The remaining industries (machinery and miscellaneous) experienced a substantial restructuring during the 1980s, which has, if anything, raised the value of their R\&D assets. In the next section I examine whether the measured rates of return to $R \& D$ in these industries support these interpretations.

\section{The Contribution of R\&D to Total Factor Productivity}

Under the reasonable assumption that investors favor higher returns over lower, the stock market places a value on R\&D spending because of its role in increasing profits and, ultimately, dividends. It is customary to divide these increases into two major areas for the purpose of analysis: reductions in cost, which come from improving the efficiency of production, and increases in revenues, which come from the introduction of new products and improvements to the old. ${ }^{43}$ To the extent that the firm is able to capture the returns to the introduction of new products (through various appropriability mechanisms such as the patent system), both sources of increased profits will generate private returns to $R \& D$ spending. It is natural to ask whether the apparent decline during the 1980 s in the market's expectation of the dividends to be generated by R\&D investment had a basis in the measured contribution of $R \& D$ to productivity growth during the period.

To answer this question, a series of production function estimations were performed, using the now standard growth accounting framework

43. See, for example, Griliches (1979). 
with $R \& D$ capital as one of the inputs. ${ }^{44}$ The equation estimated was the following:

$$
\begin{aligned}
\log S_{i t}=\alpha \log L_{i t}+\beta \log N_{i t} & +\gamma \log K_{i t} \\
& + \text { time dummies ( }+ \text { firm effects), }
\end{aligned}
$$

where $i$ denotes firms, $t$ denotes years, $S$ is deflated sales, $L$ is the number of employees during the year, and $N$ and $K$ are ordinary capital and $R \& D$ capital, respectively, both measured at the beginning of the year. ${ }^{45}$ The R\&D capital, $K$, has been constructed from R\&D investment using a declining balance formula with a depreciation rate of 15 percent. ${ }^{46}$ Equation 7 was estimated in levels and using one-year growth rates of all the variables (differenced logarithms). ${ }^{47}$ Growth-rate estimates typically show evidence of substantial downward bias from ran-

44. See Mairesse and Sassenou (1991) for a survey of previous results obtained using this methodology.

45. Obviously, the precise choice of variables was dictated by data availability, and the underlying quantities therefore were inevitably measured with substantial error. Where the results can be compared with published results that used the somewhat better data available from the Census of Manufactures (Griliches 1980a, 1986; Lichtenberg and Siegel 1991), they are reasonably close. The most important difference between the data used here and the data called for by the model concerns the double counting of R\&D expenditures (Schankerman 1981): spending on R\&D is composed primarily of the wages of scientists and engineers who are also included in the employment variables and investment in capital, which is included in the firm's capital stock. Therefore, the measured elasticity of sales with respect to R\&D capital $K$ is an elasticity that is in excess of the elasticity of sales with respect to its components. Several researchers with access to better data than those used here have estimated the bias in $\gamma$ that is produced by this mismeasurement and found it to be relatively stable across time and on the order of 0.06 within firm (Schankerman 1981; Cuneo and Mairesse 1984; Hall and Mairesse, forthcoming). In considering the elasticity estimates in this paper, it is therefore appropriate to add such a factor to the R\&D capital elasticity to obtain an estimate that more accurately reflects the total productivity of $R \& D$ investment.

46. See Hall (1990) for more details on the data set construction.

47. Level estimates of the production function in equation 6 will be contaminated by the presence of "heterogeneity bias" if firms or industries that are productive for other reasons are also those that spend resources on research and development, either because they have more funds available for investment (for example, the free cash flow story) or for other reasons. Such a situation implies that there will be permanent differences across firms in the relationship described in equation 4 that are correlated with R\&D capital and will tend to bias its coefficient upward when the equation is estimated in levels. Thus, many researchers prefer to use firm-level growth rates (logarithmic differences) to estimate the relation, and I follow this tradition here, although there is conflicting evidence in table 1 on the importance of heterogeneity bias, at least for R\&D capital. 
dom measurement error, so a series of growth-rate regressions was estimated using two-year differences, three-year, and so forth (not shown). Because the coefficient estimates tended to rise with the length of the differencing interval, but at a diminishing rate, four-year growth rates were used for the "long-differenced" estimates, as a compromise that minimized measurement error while preserving as many years of data as possible. ${ }^{48}$

The sample over which the production function model was estimated is essentially the same as that used in the previous section to estimate market valuation relations. It has been augmented with firms for which there are data on R\&D spending back to 1959 for the purpose of comparison with earlier work. Some discussion of the selectivity that may be at work during the earlier part of the period (the 1960s) is given in appendix B. After cleaning and restricting the sample to those firms that performed R\&D for at least six years (so that the long-differenced growth rates could be constructed and beginning-of-year measures of capital used), there are approximately 16,000 observations on about 1,600 firms. ${ }^{49}$

The results of estimating equation 7 are shown in table 2 . Three panels of estimates are shown: the first estimates are for variables in levels, pooled across all firms and the chosen years; the second set are estimates using four-year growth rates of the variables; and the third set are estimates using one-year growth rates. All the estimates are shown for the entire twenty-seven-year period, and for four subperiods: the 1960s (1964-70), the 1970s (1971-80), and the two halves of the 1980s (1981-85 and 1986-90). ${ }^{50}$ Substantial differences across the pe-

48. See Griliches and Hausman (1986) for further discussion of the role of measurement error in the estimation of production functions.

49. The original sample consisted of about 24,000 observations on around 2,200 firms, but many of these are relatively small with very short R\&D histories, so they did not survive the requirement of at least six years of $R \& D$. In addition, a substantial amount of exploration using robust regression methods revealed that these data are characterized by leptokurtosis in the growth rates, which tends to increase the (ordinary) standard errors and to render the estimates somewhat unstable and sensitive to outliers. Trimming the one-year growth rates at ( -67 percent, 200 percent) and the four-year growth rates at ( -50 percent, 100 percent on an annual basis) reduced this problem substantially and produced estimates that were very like those obtained using robust regression but at a much lower cost, so this type of trimming was used throughout the paper.

50. See appendix B for a discussion of the widely varying sample coverage over 
Table 2. Productivity Regressions; All Industries Pooled;

Dependent Variable: Log (Sales)

\begin{tabular}{lccccc}
\hline \multicolumn{5}{c}{ Period and number of observations } \\
\cline { 2 - 6 } Variable & $1964-90$ & $1964-70$ & $1971-80$ & $1981-85$ & $1986-90$ \\
Totals & 16,123 & 713 & 6,464 & 4,803 & 4,139 \\
$\log L$ & $0.581(0.005)$ & $0.550(0.019)$ & $0.538(0.008)$ & $0.591(0.009)$ & $0.634(0.009)$ \\
$\log N$ & $0.374(0.004)$ & $0.370(0.013)$ & $0.411(0.006)$ & $0.374(0.007)$ & $0.325(0.007)$ \\
$\log K$ & $0.032(0.002)$ & $0.043(0.015)$ & $0.030(0.004)$ & $0.024(0.004)$ & $0.040(0.004)$ \\
$R^{2}(\mathrm{~s} . \mathrm{e})$. & $0.962(0.367)$ & $0.954(0.294)$ & $0.962(0.354)$ & $0.962(0.372)$ & $0.960(0.388)$ \\
Long-diff. & & & & & \\
$\log L$ & $0.756(0.005)$ & $0.633(0.026)$ & $0.726(0.008)$ & $0.799(0.010)$ & $0.759(0.011)$ \\
$\log N$ & $0.118(0.004)$ & $0.140(0.022)$ & $0.119(0.007)$ & $0.130(0.008)$ & $0.099(0.009)$ \\
$\log K$ & $0.026(0.005)$ & $0.101(0.034)$ & $0.006(0.008)$ & $0.009(0.008)$ & $0.053(0.009)$ \\
$R^{2}(\mathrm{~s} . \mathrm{e})$. & $0.729(0.056)$ & $0.713(0.042)$ & $0.696(0.051)$ & $0.753(0.056)$ & $0.706(0.065)$ \\
First-diff. & & & & & \\
$\log L$ & $0.602(0.006)$ & $0.598(0.025)$ & $0.606(0.010)$ & $0.615(0.012)$ & $0.583(0.012)$ \\
$\log N$ & $0.115(0.006)$ & $0.025(0.023)$ & $0.114(0.010)$ & $0.107(0.012)$ & $0.129(0.011)$ \\
$\log K$ & $0.017(0.009)$ & $0.175(0.056)$ & $0.021(0.015)$ & $-0.011(0.016)$ & $0.036(0.018)$ \\
$R^{2}(\mathrm{s.e})$. & $0.445(0.135)$ & $0.548(0.089)$ & $0.455(0.124)$ & $0.434(0.142)$ & $0.413(0.148)$ \\
\hline
\end{tabular}

Source: Author's computations from Compustat data.

$L=$ number of employees; $N=$ net P\&E; $K=\mathrm{R} \& \mathrm{D}$ capital (both at beginning of year). All variables except employment are deflated. A complete set of year dummies is included in each estimation. Numbers in parentheses are standard errors.

riods in the productivity of the conventional measure of $R \& D$ capital at the firm level are immediately apparent in this table. The longdifferenced estimates, which are the most robust to both heterogeneity bias and measurement error, show that the estimated elasticity of sales with respect to R\&D capital is $0.10(0.03)$ in the 1960 s, falls to approximately zero in the $1970 \mathrm{~s}$, and rises again to about $0.05(0.01)$ at the end of the 1980s. The result for the 1960s is consistent with those of Griliches, estimated using large samples of firms from the CensusNSF RD-1 Survey. ${ }^{51}$ The only other published estimates using the production function specification at the firm level are those of Griliches and Mairesse, who used a data source like mine. ${ }^{52}$ Their estimates

these four periods. This variation explains in part why the results for the 1960s have rather larger standard errors than those for the later periods. The evidence reported in appendix B suggests that these long-lived R\&D-performing firms are indeed slightly different from the rest, with a somewhat more robust R\&D productivity, although they too suffered a decline in elasticity during the 1970 s.

51. Griliches (1980a and 1980b for 1957-65); Griliches (1986 for 1966-77).

52. Griliches and Mairesse $(1983,1984)$. 
confirm those based on Census-NSF data for 1966-77, with a withinfirm coefficient of 0.09 (0.02), and show the same kind of decline during the 1970s as mine, with a coefficient for the 1973-78 average growth rate of $0.02(0.03) .{ }^{53}$ The news in table 2 is that the measured decline in the contribution of $R \& D$ to sales productivity growth during the 1970s apparently persisted into the 1980 s but reversed sometime during the period.

Estimating relations such as equation 5 across all manufacturing industries implicitly assumes that these industries have a common production function with identical values for the coefficients $\alpha, \beta$, and $\gamma$. This seems an implausible assumption, particularly for $\gamma$, given the widely varying nature of technology in the different industries. For this reason many researchers have preferred either to focus on specific industries, or to use a "rate-of-return" formulation to estimate the returns to $R \& D$, one that implicitly assumes that the marginal product rather than the elasticity of R\&D is equalized across industries. I pursue the second approach here. ${ }^{54}$ First, I again divide the manufacturing sector into the same six major industrial sectors: chemicals, pharmaceuticals, electrical, computing, machinery, and miscellaneous. As before, firms in the aircraft and nonmanufacturing industries have been removed. Regressions like those in table 2 were computed for these six sectors, and the estimated research elasticities are summarized in table 3. As Griliches and Mairesse originally found, conclusions are difficult to draw at the industry level using the relatively sparse data for the 1960s, because of the high variability of the coefficients and large standard errors. ${ }^{55}$ In the later periods, however, even with fairly substantial standard errors, some variation in these elasticities is visible across the sectors. The chemical sector had an essentially zero or negative R\&D contribution to productivity until the late $1980 \mathrm{~s}$, but this is not true of

53. Griliches and Mairesse (1983).

54. An earlier draft of this paper also contained the results of estimation using a rate-of-return formulation, but these results tended to be very unstable across minor changes to the sample or time period and to be more sensitive to outliers than the production function specification (because of the intensity form of the variable on the right-hand side). Apparently, although one might expect the rate of return to $R \& D$ investment to be roughly equalized across sectors, this is far from true ex post. Because these results added little information that was not already in tables 2 and 3, I do not present them in this version of the paper.

55. Griliches and Mairesse (1984). 
Table 3. Estimates of the R\&D Elasticity by Industry

\begin{tabular}{lccccc}
\hline \multirow{2}{*}{$\begin{array}{l}\text { Industry } \\
\text { (No. of obs. })\end{array}$} & $1964-90$ & $1964-70$ & $1971-80$ & $1981-85$ & $1986-90$ \\
\cline { 2 - 6 } Chemicals & -0.015 & 0.075 & -0.014 & -0.083 & 0.048 \\
$(2,219)$ & $(0.015)$ & $(0.062)$ & $(0.031)$ & $(0.027)$ & $(0.029)$ \\
Pharmaceuticals & 0.102 & -0.262 & 0.150 & 0.090 & 0.097 \\
$(1,263)$ & $(0.021)$ & $(0.201)$ & $(0.037)$ & $(0.038)$ & $(0.036)$ \\
Electrical & -0.029 & 0.007 & -0.027 & -0.001 & -0.062 \\
$(2,212)$ & $(0.013)$ & $(0.082)$ & $(0.021)$ & $(0.023)$ & $(0.026)$ \\
Computers & 0.068 & -0.132 & 0.073 & 0.049 & 0.089 \\
$(2,310)$ & $(0.014)$ & $(0.071)$ & $(0.031)$ & $(0.023)$ & $(0.024)$ \\
Machinery & 0.010 & 0.066 & 0.011 & -0.004 & 0.013 \\
$(4,275)$ & $(0.008)$ & $(0.087)$ & $(0.013)$ & $(0.015)$ & $(0.018)$ \\
Other & 0.005 & 0.500 & -0.005 & -0.020 & 0.046 \\
$(3,362)$ & $(0.009)$ & $(0.065)$ & $(0.013)$ & $(0.015)$ & $(0.018)$ \\
Total & 0.026 & 0.111 & 0.007 & 0.011 & 0.051 \\
$(15,641)$ & $(0.005)$ & $(0.036)$ & $(0.008)$ & $(0.008)$ & $(0.009)$
\end{tabular}

\begin{tabular}{lccccc} 
& \multicolumn{5}{c}{ Weighted by employment size category } \\
Chemicals & 0.008 & 0.040 & 0.063 & -0.116 & 0.111 \\
& $(0.023)$ & $(0.059)$ & $(0.046)$ & $(0.039)$ & $(0.044)$ \\
Pharmaceuticals & 0.114 & 0.030 & 0.146 & 0.177 & 0.042 \\
& $(0.023)$ & $(0.168)$ & $(0.030)$ & $(0.036)$ & $(0.045)$ \\
Electrical & -0.036 & -0.028 & 0.052 & -0.090 & -0.082 \\
& $(0.014)$ & $(0.083)$ & $(0.022)$ & $(0.023)$ & $(0.027)$ \\
Computers & 0.079 & 0.042 & 0.207 & -0.010 & -0.012 \\
& $(0.014)$ & $(0.084)$ & $(0.026)$ & $(0.022)$ & $(0.028)$ \\
Machinery & 0.044 & 0.160 & 0.014 & 0.108 & -0.050 \\
& $(0.008)$ & $(0.071)$ & $(0.013)$ & $(0.013)$ & $(0.020)$ \\
Other & 0.001 & 0.648 & 0.002 & -0.044 & 0.014 \\
& $(0.008)$ & $(0.066)$ & $(0.016)$ & $(0.013)$ & $(0.015)$ \\
Total & 0.038 & 0.198 & 0.037 & 0.023 & 0.033 \\
& $(0.005)$ & $(0.030)$ & $(0.010)$ & $(0.008)$ & $(0.009)$ \\
\hline
\end{tabular}

Source: Author's computations using Compustat data. Estimates are from four-year growth rate equations like those in table 2 . See the text for details on the industry breakdown. The weights are the geometric mean of employment in each of ten size categories. Numbers in parentheses are standard errors.

the pharmaceutical sector, which was undoubtedly not hit in the same way by the oil price shocks during the 1970s. The machinery and miscellaneous sectors also experienced a decline in R\&D productivity during this period, but they recovered somewhat more quickly than chemicals did. The computing and electronics sector suffered hardly any decline in the potency of R\&D investment during the 1970s.

The firms for which these estimates have been computed have a very wide size distribution, with an overall range of 16 employees to 876,000 
employees and an interquartile range of 1,000 to 15,000 employees. The unweighted regressions in table 2 and the top half of table 3 treat all these firms equally, even though their effect on the aggregate economy varied substantially. This would not matter if the underlying relationship between productivity and $R \& D$ were truly linear and the research elasticity were constant across firms, because the relative weight attached to each observation would not affect the estimated elasticity. These conditions are unlikely to hold in practice, and one way to assess the importance of differences in the elasticity as a function of firm size is to compute estimates from data weighted by the size of the firm. Because of the large size range in these data, however, such a procedure tends to put too much weight on a few very large firms, so the alternative of grouping the firms into ten different size classes and then weighting each group by the geometric mean of employment in each class was used.

These estimates are shown in the bottom panel of table 3 , and they reveal several interesting differences between the larger and smaller firms in the sample. The first is that the decline in R\&D productivity in the chemical industry now occurs between the early and latter half of the 1980s, although it is also low in the 1970s. For pharmaceuticals, the larger firms show a substantial drop in the contribution of R\&D to productivity during the late 1980 s. In the machinery sector the results are quite unstable, but they seem to indicate that the larger firms have negative returns to $R \& D$ investment in the late 1980s (the three largest firms in this sector are the three major automobile manufacturers). The most interesting result in this table concerns the electrical and especially the computing sectors: the weighted results show no contribution of R\&D to productivity during the 1980 s, whereas the unweighted results have fairly good-sized coefficients. This contrast no doubt reflects the differing experience of the older large mainframe computer manufacturers and their newer and smaller competitors, both in personal computers and in electronic components. The productivity regression says that the growth of R\&D spending in the larger firms from 1978 to 1987 had almost no impact on the sales productivity of these firms ex post, whereas R\&D had a fairly substantial effect on the sector as a whole.

Overall, these results show a weakening but continuing contribution of R\&D to sales productivity growth during the 1980 s relative to the 1960 s, but with substantial cross-industry variation. How do they com- 
pare with the equity market's forecast of the ability of R\&D to generate supranormal returns in these sectors $?^{56}$ In the chemical, machinery, and miscellaneous sectors, the increase in the contribution of $R \& D$ to productivity during the 1980 s parallels the rise in equity value of $R \& D$ in these industries, although this is not true for the larger firms in the machinery industries. The continued high valuation of $R \& D$ in pharmaceuticals seems to be justified by the fairly high R\&D elasticity estimated for this industry throughout the period. The negative R\&D elasticity in the electrical sector in the second half of the 1980s is entirely consistent with the low valuation placed on these assets since 1984. The only real mystery is the computing sector, where the overall R\&D elasticity is positive throughout the period (although it is approximately zero for the larger firms), while the equity markets apparently wrote off this investment in about 1986.

\section{Discussion and Conclusion}

The findings in this paper can be summarized in the following way. First, the absolute market value of both new and old R\&D fell substantially during the 1980s. Second, this decline happened in an environment where the publicly traded manufacturing sector was being very substantially restructured, with assets (including R\&D assets) moving out of chemicals, metals, machinery, autos, and some electrical-based industries and into the high-technology sectors of pharmaceuticals, computing, and electronics. Some of the valuation changes can be attributed to this restructuring. If the equity markets are a guide, the restructuring was successful, at least for the private returns in industry. Third, during the same period, the three major high-technology sectors, pharmaceuticals, electrical, and computing, have experienced a rather different evolution in both the valuation of and the rate of return to R\&D investment. Both remained high in pharmaceuticals throughout

56. To make a direct comparison with $\Pi_{K}$, the marginal product of $\mathrm{R} \& \mathrm{D}$ capital, the sales elasticity of $R \& D$ has to be multiplied by an estimate of the sales-to- $R \& D$ capital ratio. For the chemical and machinery sectors, these numbers are about 10 throughout the 1970s and 1980s. For pharmaceuticals and computers, they fall from about 5 in the 1970 s to 3.3 by the end of the 1980 s, while for the electrical sector, the fall is from 5.5 to 3.5 . In the miscellaneous sector, the ratio of sales-to-R\&D capital is 20 throughout. 
the 1970s and 1980s, while in the electrical and computing sectors the raw market value fell steeply, and the productivity of that R\&D was negative except in the small-scale computing and electronics firms. ${ }^{57}$

How can these findings be reconciled? A model of firm value that decomposes the excess of market value over the book value of the physical assets into the value of the existing R\&D capital plus the present discounted value of the stream of rents (excess of profits over the cost of capital) that are expected to accrue from new investments suggests that the correct interpretation of the market value finding is that the commonly used measure of $R \& D$ capital, which is computed using a 15 percent depreciation rate, overstates the privately productive capital available to the firm in the later part of the period, particularly for the electrical and computing sectors. This is consistent with casual empiricism, which suggests that these industries have become more competitive, with a great deal of entry, some of it foreign and imitative in nature, and where lead times have gotten shorter and shorter. It is not surprising that the depreciation rate for the private returns is higher in such a setting. The contrast with the chemical and pharmaceutical sectors, where old R\&D capital has maintained its value along with new, albeit at a somewhat lower level than the high-flying early 1980s, is quite striking.

The fact that the rents to $R \& D$ may be dissipated more quickly in the current economic environment does not mean that the measured rate of return to $R \& D$ will necessarily fall very much. Recall that the valuemaximizing firm is attempting to set the expected profit rate from an increment to $R \& D$ capital equal to its cost. The depreciation rate in the cost-of-capital formula presumably summarizes the diminution of the ability of $R \& D$ capital to generate private returns. If this rate rises, the cost of capital will also rise, requiring a higher expected profit rate just to break even. I believe that this story accounts for the apparent robustness of the rate of return to R\&D in the face of a stock market that is extremely doubtful about its profitability. The message conveyed by these results is that the social returns to $R \& D$ may have diverged even

57. Where they can be compared (the all-industry level and first-differenced estimates), the elasticities estimated in this paper are somewhat higher in the late 1980s than that estimated by Mairesse and Hall (1993), which was around 0.02 for the whole period 1981-88. This is consistent with the fact that the early half of the 1980s had a somewhat lower estimate than the latter half. 
more from the private returns in the 1980 s as the private returns dissipated more quickly, at least in some sectors. The R\&D tax credit, which became fairly large by the end of the period (where it is responsible for a drop of approximately 200 basis points in the cost of capital according to calculations reported here), may have helped to moderate the effects observed here, but it has by no means eliminated them.

Although this story is broadly consistent with the evidence at hand and the views of observers of technological competition, it is still somewhat speculative and deserves further investigation. Fruitful areas for future work would seem to be tightening up the link between the market valuation model sketched in appendix $A$ and the estimates shown in figures 2,3 , and 4 , so that an estimate of the growth forecast and private depreciation rate might be extracted from these numbers. The industrylevel estimates also need further exploration to see if disaggregation into more homogeneous sectors would help in interpreting the results. For example, sweeping changes in the petroleum and chemicals industries in the late 1970s or in the machinery, metals (both primary and fabricated), motor vehicles, and engines industries in the early $1980 \mathrm{~s}$ are now combined together, making it hard to see exactly what is going on. Finally, there is the issue of data quality. The exercises here push the publicly available data about as far as they can go. It is reassuring that the production function estimates are as close as they are to those made with the higher quality census data, but it would seem worthwhile to extend the work of Lichtenberg and Siegel to the end of the 1980s, making use of the industrial detail available in those surveys. ${ }^{58}$

\section{Appendix A: A Model of the Market Value of a Firm}

In this appendix I sketch the market valuation model that underlies the estimates presented in the paper. The model is derived from a dynamic programming model of a firm with multiple capital stocks, presented by Hayashi and Inoue, ${ }^{59}$ but it is not intended to be a precise description of reality. The purpose here is to provide an interpretive framework for understanding the regression coefficients reported in figures 2, 3, and 4. To derive equation 1 , assume that the stock market

58. Lichtenberg and Siegel (1991).

59. Hayashi and Inoue (1991). 
values a firm that has capital stocks $A$ (ordinary capital) and $K$ (R\&D capital) as though the firm is maximizing the present discounted value of the future profit and cost of these capitals. Like Hayashi and Inoue, I will assume that the capitals can be aggregated into a single capital using a homogeneous aggregator function $\phi(A, K) .{ }^{60}$

$$
\begin{aligned}
& V\left(A_{t}, K_{t}\right)=\operatorname{Max}_{\left(A_{\mathrm{t}} K_{\mathrm{t}}\right)} P V_{t}\left\{\Pi\left[\phi\left(A_{t}, K_{t}\right)\right]-p_{i} I_{t}-p_{r} R_{t}\right\}, \\
& \text { subject to } \dot{A}_{t}=I_{t}-\delta_{i} A_{t} \text { and } \dot{K}_{t}=R_{t}-\delta_{r} K_{t},
\end{aligned}
$$

where $\phi\left(A_{t}, K_{t}\right)$ is the capital aggregator, $\Pi(\phi)$ denotes the variable profits (gross of capital costs but net of variable costs such as labor and materials) from the aggregate capital $\phi\left(A_{t}, K_{t}\right), I_{t}$ is current investment, $R_{t}$ is current R\&D investment, $p_{i}$ and $p_{r}$ are their respective prices, and $\delta_{i}$ and $\delta_{r}$ are the depreciation rates of ordinary and R\&D capital from the perspective of the private rate of return.

Hayashi and Inoue show that the value of the firm for this problem can be expressed as the sum of two pieces: the current capital stock valued at replacement cost plus a term that is the present discounted value of the gap between the marginal product of the capital and the cost of the same capital. This latter represents the rents accruing to this particular firm as a consequence of its particular position in asset space, scale economies (if $\Pi$ and $\phi$ are not linear homogeneous), and differential access to factors (so that other firms do not enter and drive the marginal product of capital all the way down to its cost). This term also isolates any effects of uncertainty. If the $P V$ computation is an expected present discounted value computation, the rent term will also contain an expectation.

The same authors show that the maximization problem can be solved in two stages, where the first-stage problem finds the optimal shares of each capital in the overall aggregate, and the second stage finds the rent-maximizing level of $\phi$. Using this approach, the value of the firm

60. This formulation abstracts from the variable inputs, which are assumed to be chosen optimally conditional on the capital stock every period. Adjustment costs have also been ignored, because they add nothing essential to the derivation; if they are present, the cost of each capital will incorporate the marginal adjustment cost in addition to the interest rate and depreciation rate. See Hayashi (1982) and Hayashi and Inoue (1991) for details. 
as a function of its current position can be written in the following way after solving the first-stage problem:

$$
\begin{aligned}
V\left(A_{t}, K_{t}\right)=p_{i} A_{t}+ & p_{r} K_{t} \\
& +\underset{\left\{A_{\mathrm{t}}, K_{\mathrm{t}}\right\}}{\operatorname{Max} P V_{t}\left\{\Pi\left[\phi\left(A_{t}, K_{t}\right)\right]-c_{i} A_{t}-c_{r} K_{t}\right\},}
\end{aligned}
$$

where the costs of capital, $c_{j}$, are defined as

$$
c_{j}=p_{j}\left(\rho+\delta_{j}-\dot{p}_{j} / p_{j}\right) \text { for } j=i, r,
$$

and where $\rho$ is the discount rate used in the present value computation. Along the optimal path for capital stocks, the ratios of the cost of capital for each capital to its marginal effect on the capital aggregate are equal to a single shadow price $\lambda$ (the shadow price of the capital aggregator identity):

$$
c_{i} / \phi_{A}\left(A_{t}, K_{t}\right)=c_{r} / \phi_{K}\left(A_{t}, K_{t}\right)=\lambda\left(c_{i}, c_{r}\right) .
$$

Under the assumption that the capital aggregator $\phi$ is linear homogeneous, the solution for the second-stage problem is ${ }^{61}$

$$
\begin{aligned}
V\left(A_{t}, K_{t}\right)=p_{i} A_{t}+p_{r} K_{t} & \\
& +P V_{t}\left\{\left[\Pi_{\phi}\left(A_{t}, K_{t}\right)-\lambda\left(c_{i}, c_{r}\right)\right] \phi\left(A_{t}, K_{t}\right)\right\} .
\end{aligned}
$$

In the absence of adjustment costs and uncertainty and when $\Pi$ and $\phi$ are linear homogeneous, the $P V$ term in this equation will always be zero, period by period, and the market value of the firm will simply be the replacement value of its stocks. Interpreting the regressions in the paper requires an assumption that the last term in this valuation equation is not zero and that the firm does indeed expect to earn supranormal (or subnormal) returns from its capital stock. To make this idea concrete, I assume a particularly simple form for the capital aggregator function, one where the stocks simply enter additively but with relative coefficients that are not equal to unity:

61. The assumption of linear homogeneity is made here for convenience and because ultimately I will use a specific linear homogeneous form for $\phi$. Homogeneity of any degree would be sufficient to solve the second-stage problem easily; in general, it would yield a form for the cost of the capital aggregator, which is not linear in the capital stock. 


$$
\phi\left(A_{t}, K_{t}\right)=A_{t}+\gamma K_{t} .
$$

Note that $\gamma$ represents the relative marginal product of $R \& D$ capital in the profit function because

$$
\frac{\partial \Pi / \partial K}{\partial \Pi / \partial A}=\frac{\Pi_{\phi} \gamma}{\Pi_{\phi}}=\gamma .
$$

With this assumption, the value function for the firm can now be written in the following manner:

$$
\begin{aligned}
V\left(A_{t}, K_{t}\right)=p_{i} A_{t}+P V_{t}\left[\left(\Pi_{\phi}-\lambda\right) A_{t}\right] & \\
& +p_{r} K_{t}+P V_{t}\left[\left(\Pi_{\phi}-\lambda\right) \gamma K_{t}\right] .
\end{aligned}
$$

To obtain the equation used for estimation, take logarithms of both sides, using the approximation $\log (1+\epsilon) \cong \epsilon$ for all terms but the first, and subtract the first term on the right-hand side from the market value to obtain an expression for the logarithm of Tobin's $Q$ for the firm as a function of its rents:

(A9) $\log Q\left(A_{t}, K_{t}\right)=\frac{P V_{t}\left[\left(\Pi_{\phi}-\lambda\right) A_{t}\right]}{p_{i} A_{t}}$

$$
+\frac{p_{r} K_{t}}{p_{i} A_{t}}+\gamma \frac{P V_{t}\left[\left(\Pi_{\phi}-\lambda\right) K_{t}\right]}{p_{i} A_{t}} .
$$

The deviation of the market value of the firm from its book value thus comprises three terms: the present value of the returns to ordinary capital above and beyond those that cover its cost, the relative magnitude of its R\&D capital, and the present value of the supra- or subnormal returns to $\mathrm{R} \& \mathrm{D}$ capital. As indicated above, the first and third of these terms will be zero in a long-run steady state with constant returns, leaving only a term resulting from the fact that the measured book value of the firm's capital does not include the R\&D capital. In practice the coefficient of the second term is not estimated to be unity when only current stocks are included in a regression for $\log Q$, implying that the assumptions of a constant returns steady state and zero rents to the firm are clearly counterfactual. ${ }^{62}$

Equation A9 can be stated in a way that is more useful for interpreting

62. See Hall (1993c) for more detailed evidence on these estimates. 
the sources of the valuation changes for $R \& D$ investment by assuming that expectations of future returns and costs are equal to their value today and that R\&D capital $K_{t}$ (and R\&D spending $R_{t}$ ) has a specific (geometric) growth process. ${ }^{63}$ The valuation of $R \& D$ capital can then be decomposed into the total return from existing capital (for which costs are sunk) and the excess returns from future $R \& D$ investments. To do this, I focus only on the part of market value that is associated with R\&D capital, denoted $V\left(K_{t}\right)$, and I assume for the moment that the coefficient of $K_{t}$ in the capital aggregator $(\gamma)$ is unity; under these assumptions, the value of the $R \& D$ capital portion of equation $A 8$ is

$$
V\left(K_{t}\right)=p_{r} K_{t}+E_{t} \int_{0}^{\infty} e^{-\rho s}\left(\pi_{r}-c_{r}\right) K_{t+s} d s,
$$

where $\pi_{r}$ is the marginal product of R\&D capital and $c_{r}$ is the cost of R\&D capital, both assumed constant in expectation. ${ }^{64}$ Under the assumption that investment, $R_{t}$, grows at a constant rate $g$ (with $g$ less than the discount rate $\rho$ ) in the infinite future, it can be shown that the integral in equation A10 is equal to the following expression:

$$
\frac{\left(\pi_{r}-c_{r}\right)}{\left(\rho+\delta_{r}\right)}\left(K_{t}+\frac{R_{t}}{(\rho-g)}\right) .
$$

The two terms in this expression are the capitalized excess returns from existing R\&D capital plus the capitalized excess returns from the stream of future $R \& D$ expenditures, which are higher if $R \& D$ is growing faster. This decomposition implies that the total value of the $R \& D$ part of the firm can be written as a function of the stock of R\&D capital and the instantaneous flow of $R \& D$ expenditure:

63. This assumption is made solely for convenience; it will not necessarily be the solution to the firm's optimal dynamic program. Solving the true dynamic programming problem under uncertainty is an extremely complex process, however, and one as unlikely to be performed by the firm as by the econometrician. The current growth rate of R\&D spending is a useful one-parameter summary of the differences across firms in the expected value of the part of future profits that is not due to the current level of capital.

64. One consequence of this assumption is that $\dot{p}_{r}$ is assumed to be zero into the infinite future. 


$$
\begin{aligned}
& V\left(K_{t}\right)=E_{t}\left\{\left[\pi_{r} /\left(\rho+\delta_{r}\right)\right] K_{t}\right\}+ \\
& E_{t}\left\{\left[\pi_{r} /\left(\rho+\delta_{r}\right)-P_{r}\right] R_{t} /(\rho-g)\right\} .
\end{aligned}
$$

The first term is the expected value of the profits to be earned from the stock of R\&D under the assumption that net (not gross) new R\&D is zero; it is equal to $K_{t}$ in steady state equilibrium when the marginal product of $R \& D$ capital is just equal to the cost of $R \& D$ capital. The second term is expected value of the excess profits to be earned from future $\mathrm{R} \& \mathrm{D}$, beyond the amount necessary to cover its cost $\left(p_{r}\right)$. In the body of the paper, I use net new R\&D investment as a proxy for the second term (and similarly for ordinary investment).

The difference between equations $\mathrm{A} 8$ and $\mathrm{A} 12$ is that in $\mathrm{A} 8$ the decomposition is between earnings from past capital, assuming that it earns no excess returns, plus another term that contains all of the returns above the cost of capital for both old and new R\&D capital. Equation A12 decomposes the expression so that the excess returns from old R\&D capital go into the first term. Because the behavior of gross R\&D investment is very smooth over time and typically is high enough to maintain the existing level of $R \& D$ capital at reasonable depreciation rates (15-20 percent), the formulation in A12, which clearly distinguishes between old $R \& D$ and incremental new $R \& D(R \& D$ capitalized using a growth rate factor), is more useful for regression purposes than A8, where the current level appears in both terms.

\section{Appendix B: Sample Coverage}

The data used in this paper come from a panel data set constructed over the last fifteen years at the National Bureau of Economic Research from Standard and Poor's Compustat tapes. The data set contains balance sheet and income statement data for more than 3,000 manufacturing firms from 1959 to $1991 .{ }^{65}$ Although they provide good information about the financial characteristics of the firms, including their investment spending, these data have deficiencies for the detailed analysis of production. They are aggregated to the firm level across several differ-

65. The data set is described more fully in Hall (1990); Hall and others (1988); and Bound and others (1984). 
ent industries in many cases, and the only information on labor is the total number of employees in the firm. These data are widely available and public, however, which makes them fairly easy to combine with other sources. This appendix compares the coverage of these data with the coverage of other sources, focusing on industrial $R \& D$ spending. The appendix also explores further the source of the discrepancy between the National Science Foundation (NSF) and Compustat aggregate $\mathrm{R} \& \mathrm{D}$-to-sales ratios shown in figure 1 .

The original universe of coverage for the data set was all New York Stock Exchange and American Stock Exchange firms on the Industrial Compustat files in 1978 (including exits from the exchanges between 1976 and 1978, found on the Annual Industrial Research file); to these were added over-the-counter (OTC) firms beginning with the 1980 tape (data back to 1961). ${ }^{66}$ Because of the growth in OTC and NASDAQ firms in general and also because of the way Compustat has increased coverage over the years, the data in the 1980 s include far more smaller OTC firms than the data for the earlier periods. Furthermore, until 1972 neither the Securities and Exchange Commission nor the FASB (Financial Accounting Standards Board) generally required the reporting of R\&D spending in the accounting statements and 10-Ks from which Compustat draws its data, so coverage is a bit thin before around 1974 .

The changing coverage of the sample is illustrated in figures B-1 and B-2. Figure B-1 shows the total number of firms in the manufacturing sector on Compustat in each year, the number of these firms that report $\mathrm{R} \& \mathrm{D}$, and the number of firms that were in the original sample studied by Griliches and Mairesse, which was based on 157 firms that reported R\&D data in their annual reports as early as 1960 , augmented in a few cases by numbers obtained from Nadiri and Bitros. ${ }^{67}$ The increase in the total number of firms shown on this figure between 1964 and 1972

66. Excluded from the sample are about 120 large foreign firms that are traded on the New York and American Stock Exchanges, either as ADRs or in conventional shares. In addition, the 1991 Compustat contains multiple records for about 50 firms that were affected in a major way by FASB requirements that the balance sheets be consolidated with those of their financial subsidiaries. Because combining entities that are essentially lending institutions with manufacturing corporations destroys the informational content in the balance sheet about the manufacturing operation, Compustat has chosen to keep separate records, one under the new regulation, and one labeled "PRE-FASB" under the old. I used only one of the records for each of these firms, to avoid double counting. I am grateful to Michael Jensen for pointing out this problem to me.

67. Griliches and Mairesse (1984); Nadiri and Bitros (1980). 
Figure B-1. U.S. Manufacturing Sample from Compustat, Sample Coverage, 1964-90

Number of firms

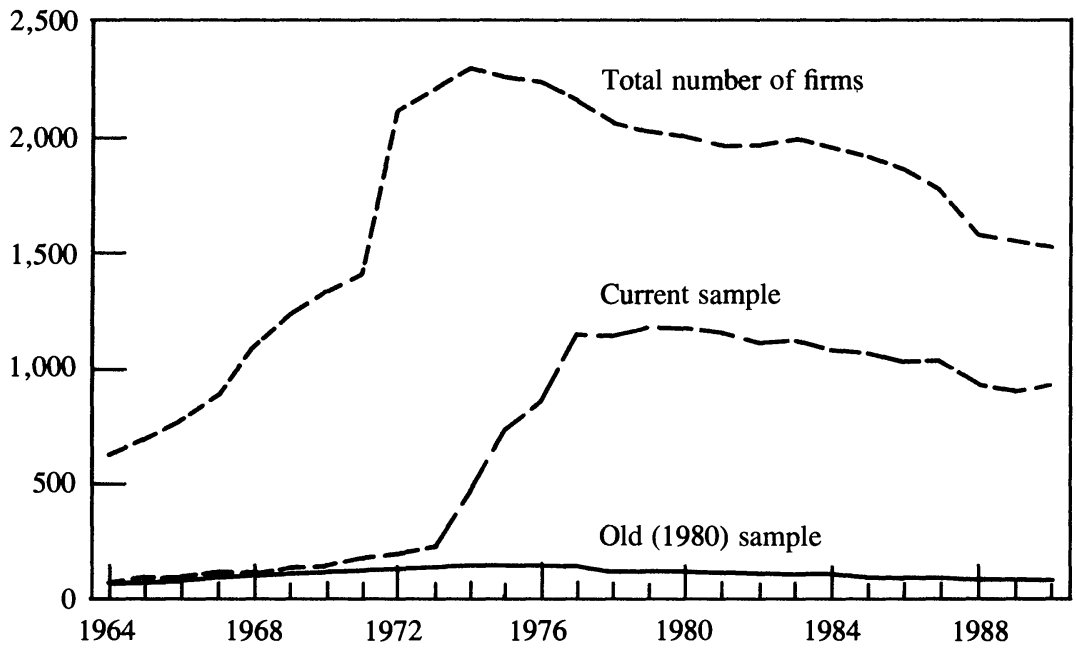

Source: Standard and Poor (1991 and earlier editions); Griliches and Mairesse (1984).

Figure B-2. Total R\&D in U.S. Manufacturing Sector, NSF and Compustat, 1964-90

Billions of 1982 dollars

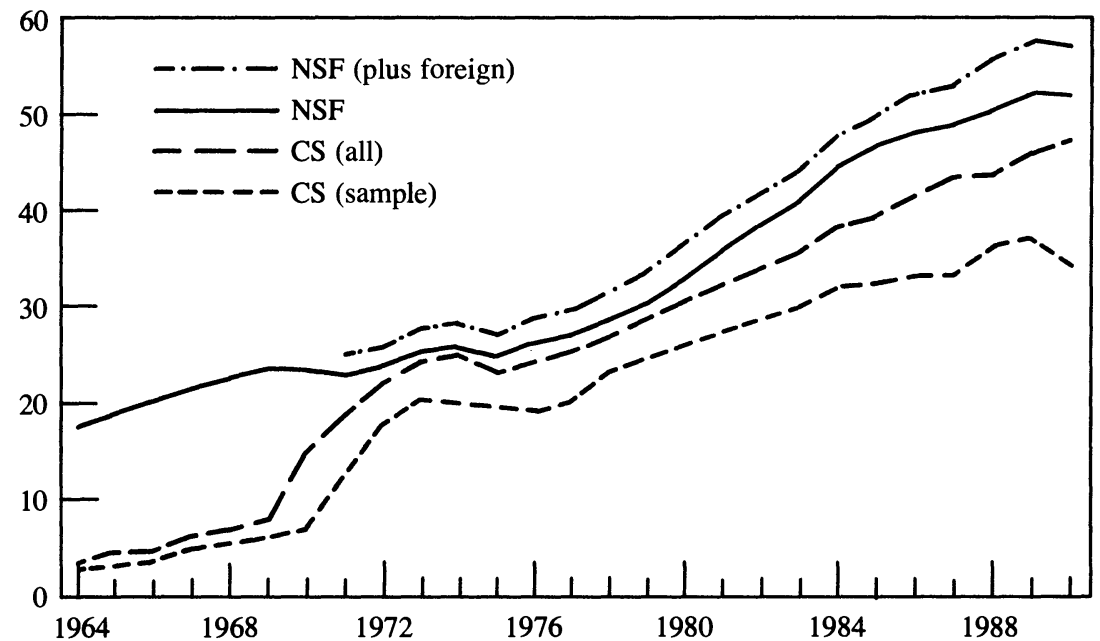

Source: National Science Foundation (1991); Standard and Poor (1991 and earlier editions). 
Figure B-3. Total Manufacturing Sales or Shipments, All Firms and R\&D-Performing Firms, 1971-90

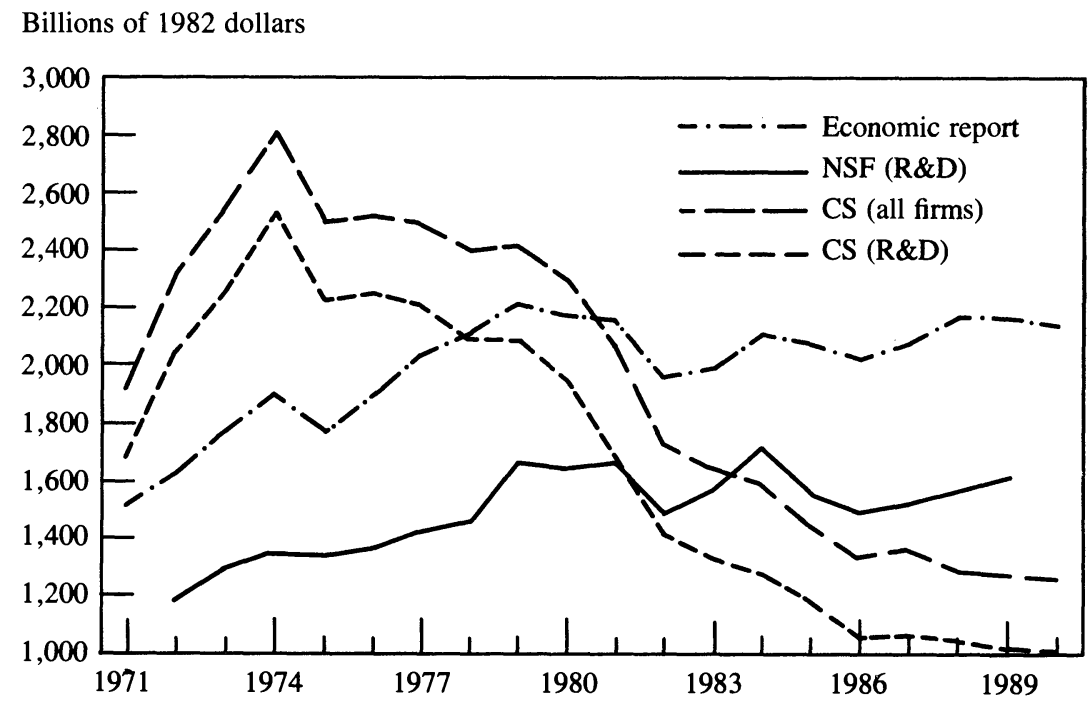

Source: Economic Report of the President (1993); National Science Foundation (1991); and Standard and Poor (1991 and earlier editions).

results primarily from changing Compustat coverage. ${ }^{68}$ The large entry in 1972 itself reflects the great number of new firms in the 1991 OTC tape that were not in the last file used previously (1987); the decline since about 1974 reflects the shrinkage of the publicly traded manufacturing sector.

Figure 1 of the paper showed that trends in the aggregate R\&D-tosales ratio in manufacturing during the 1980s differed substantially, depending on whether Compustat or NSF numbers were used. Figures B-2 and B-3 report on the numerator and denominator of the ratio of R\&D to sales separately, in an effort to find the source of the discrepancy between the two data sources. Figure B-2 shows that the total R\&D figures have tracked each other pretty well: although an increasing amount of R\&D spending takes place outside the publicly traded manufacturing sector, the fraction has remained constant at about 20 percent

68. The figures begin in 1964 because that is the first year of data actually used in the estimation described in the text. Six years of data back to 1959 are required to use beginning-of-year capital and to construct the four-year growth rates. 
from 1974 through $1990 .^{69}$ Two of the four lines on the figure correspond to aggregate manufacturing spending numbers from the National Science Foundation and two to the data from the Compustat files. ${ }^{70}$ The data from NSF are for all R\&D funded by manufacturing companies; the higher curve includes in this total R\&D funded by U.S. companies but performed abroad. It is this series that is comparable to the Compustat series, because the accounting numbers are for worldwide operations. ${ }^{71}$ The two series shown for Compustat are the total for all manufacturing corporations and the total for the firms that are actually used in the firm-level analysis in this paper; the discrepancy between these two series is caused primarily by the entry of new firms, because I require at least three years or so of data for lags and the construction of stocks.

If one looks at the denominator (sales) using figure B-3, the explanation for the difference between the economy-wide manufacturing R\&D intensity and that for publicly traded corporations becomes clear. While the real sales of the Compustat firms have fallen by a factor of two since 1974 (despite an increase in sample size due to OTC-NASDAQ entry), those for the NSF R\&D survey rose in the 1970s and then were flat during the $1980 \mathrm{~s} .^{72,73}$ Thus, the explanation for the discrep-

69. The figure also shows quite clearly the effect of the twin requirements by FASB and the SEC that firms report R\&D spending in their accounting statements and 10-Ks if the spending is "material." The requirements were instituted around 1972, and Compustat coverage shows a substantial increase between 1969 and 1972. The lack of reporting earlier means that discrepancies before about 1973 in figure 1 are not meaningful.

70. National Science Foundation (1991); Standard and Poor (1991 and earlier editions).

71. In other ways the definition of R\&D spending from the two sources (Compustat and NSF) is not identical, but it is comparable. In both cases only company-funded, rather than total, $R \& D$ spending is included in the measure, which excludes a large amount of defense-related R\&D.

72. The GDP deflator (Economic Report of the President 1993, table B-3) was used to deflate all the sales numbers in figure B-3 on the ground that real sales, rather than real output, is the relevant concept for comparison with $R \& D$ expenditures. As is wellknown by now, the manufacturing shipments deflator during the $1980 \mathrm{~s}$ is dominated by the fall in the hedonic price of computers (the shipments deflator falls by 33 percent during the 1980 s, whereas the GDP deflator rose by about 50 percent).

73. Figure B-3 also shows manufacturing shipments as reported by the Bureau of Economic Analysis and published in the Economic Report of the President (1993, table B-54). The NSF sales figures appear to track these pretty well and are typically about 75 percent of the total. 
Figure B-4. Cumulative Exits from Compustat, Foreign and Private Acquisitions

Share of sales in 1976

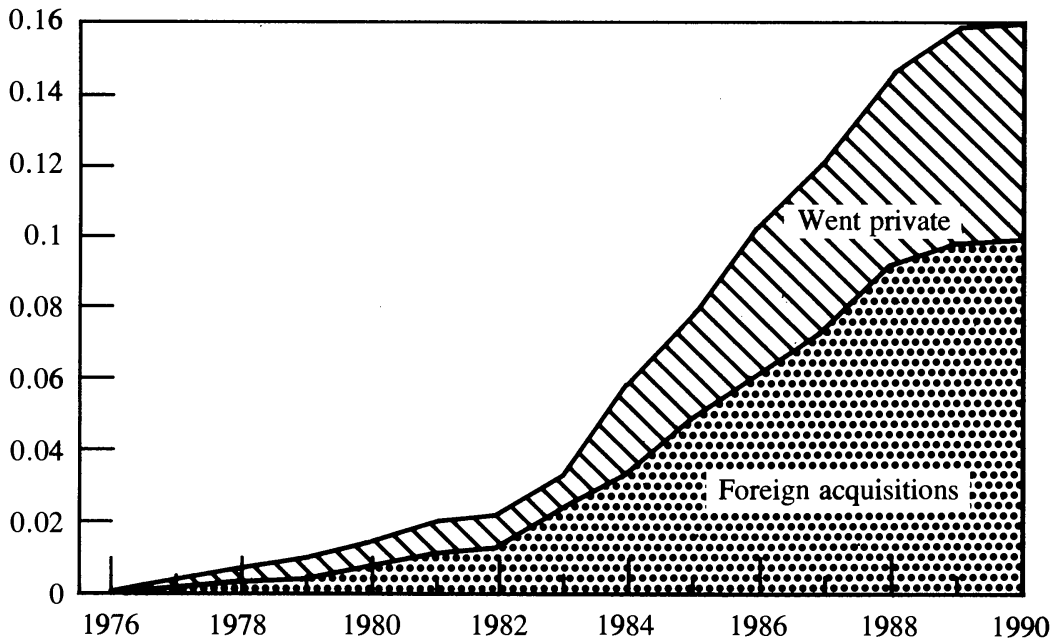

Source: See text.

ancy shown in figure 1 of the paper appears to be quite simple: manufacturing firms that are not R\&D-intensive have increasingly withdrawn from or not entered the public equity market.

Although exit from the publicly traded manufacturing sector, either because firms went private or were acquired by a foreign-owned corporation, accounts for some of the decline in sales shown in figure B-3 (and for the corresponding increase in R\&D intensity), it cannot be the whole story. Figure B-4 shows the cumulative share of total 1976 Compustat manufacturing sales for firms that had exited by either private or foreign acquisition by 1990 . Sixteen percent of 1976 real manufacturing sales corresponds to $\$ 400$ billion (in 1982 dollars), which closes about half of the $\$ 900$ billion gap shown in figure B-3. Similarly, adding these firms back into the sample with their R\&D intensity set to the value at the time of acquisition would lower the R\&D intensity of R\&D-performing firms in the final year (1990) from about 4.5 percent to 4.0 percent, which goes in the right direction but not far enough.

In any case, it is unclear whether the NSF figures include the portion of foreign firms that operate in the United States; much of the exit by foreign acquisition will leave the physical assets of the firm in the 
United States, and presumably these assets will still generate domestic manufacturing shipments. The fact that the NSF sales for R\&D-performing firms track manufacturing shipments so closely makes it likely that the NSF is somehow still including the domestic portion of these firms in the survey. ${ }^{74}$ In any case, the firms that exited from my sample because of foreign acquisition were more $R \& D$-intensive than those that went private, so they cannot account for much of the widening gap in R\&D intensity between all manufacturing and publicly traded manufacturing. A more likely culprit is the increased output from firms that have never been in my sample, such as Japanese auto manufacturers; the output of these firms will be in total manufacturing shipments, but their U.S-based R\&D spending is presumably low. According to Department of Commerce data, the 1987 sales in manufacturing by U.S. affiliates of foreign firms was $\$ 225$ billion. Of this about $\$ 70$ billion could be accounted for by the foreign firms that exited my sample, leaving another $\$ 155$ billion of sales that may have very low $R \& D$ intensity.

To make interdecade comparisons of $R \& D$ productivity, one should keep in mind the other striking feature of figure B-3: the steep rise from 1973 to 1977 in the number of firms that report R\&D, as the firms gradually came into conformance with the new FASB requirements. Clearly, the original sample of about 150 R\&D-performing firms was a small, possibly biased subset of the total.

To assess the effect of the changing sample coverage on the results in tables 2 and 3 of the paper, the same estimations were performed for a set of firms from the original (1980) sample of Griliches and Mairesse.$^{75}$ This sample of about 140 firms was updated to 1991 with some loss of coverage due to merger and bankruptcy (approximately 90 firms survived to the end of the period). Table B-1 shows estimates of the

74. Important large exits of this kind that may still be in the aggregate data are Fairchild ( $\$ 50$ million of R\&D, acquired by Schlumberger in 1979), Shell Oil Co. (\$217 million of R\&D, acquired by Royal Dutch Shell in 1985), Chesebrough-Pond's (\$67 million of R\&D, acquired by Unilever NV in 1987), North American Philips Corporation ( $\$ 113$ million of R\&D, acquired by Philips NV in 1987), Standard Oil Co. (\$125 million of R\&D, acquired by British Petroleum in 1987), Firestone ( $\$ 84$ million of R\&D, acquired by Bridgestone in 1988), and Smithkline-Beckman Corp. ( $\$ 495$ million of R\&D, merged with Beecham PLC in 1989). In some cases-Shell Oil and North American Philips, for example-the transaction seems to be a consolidation of the financial accounting rather than a substantive transaction, and yet it may still affect the data.

75. Griliches and Mairesse (1984). 
Table B-1. Productivity Regressions-Old (1980) Sample;

Dependent Variable: Log (Sales)

\begin{tabular}{lccccc}
\hline \multicolumn{5}{c}{ Period and Number of Observations } \\
\cline { 2 - 6 } Variable & All years & $1964-70$ & $1971-80$ & $1981-85$ & $1986-90$ \\
\hline Totals & 2,460 & 562 & 1,095 & 452 & 351 \\
$\log L$ & $0.479(0.012)$ & $0.554(0.021)$ & $0.470(0.019)$ & $0.431(0.028)$ & $0.474(0.028)$ \\
$\log N$ & $0.449(0.007)$ & $0.330(0.015)$ & $0.482(0.011)$ & $0.494(0.018)$ & $0.469(0.019)$ \\
$\log K$ & $0.049(0.009)$ & $0.090(0.018)$ & $0.019(0.015)$ & $0.047(0.021)$ & $0.063(0.019)$ \\
$R^{2}(\mathrm{~s}$. e. $)$ & $0.964(0.302)$ & $0.964(0.272)$ & $0.965(0.310)$ & $0.963(0.311)$ & $0.966(0.276)$ \\
Long-diff. & & & & & \\
$\log L$ & $0.667(0.014)$ & $0.616(0.029)$ & $0.712(0.022)$ & $0.629(0.030)$ & $0.693(0.042)$ \\
$\log N$ & $0.104(0.013)$ & $0.186(0.026)$ & $0.077(0.017)$ & $0.143(0.033)$ & $-0.012(0.040)$ \\
$\log K$ & $0.087(0.018)$ & $0.054(0.041)$ & $-0.015(0.028)$ & $0.198(0.040)$ & $0.249(0.045)$ \\
$R^{2}(\mathrm{~s} . \mathrm{e})$. & $0.718(0.041)$ & $0.762(0.043)$ & $0.628(0.041)$ & $0.761(0.039)$ & $0.618(0.040)$ \\
First-diff. & & & & & \\
$\log L$ & $0.573(0.016)$ & $0.578(0.030)$ & $0.593(0.025)$ & $0.504(0.036)$ & $0.577(0.040)$ \\
$\log N$ & $0.058(0.015)$ & $0.019(0.027)$ & $0.066(0.024)$ & $0.028(0.042)$ & $0.134(0.037)$ \\
$\log K$ & $0.077(0.033)$ & $0.158(0.065)$ & $-0.004(0.050)$ & $0.168(0.081)$ & $0.046(0.086)$ \\
$R^{2}(\mathrm{~s}$. e. $)$ & $0.501(0.091)$ & $0.494(0.089)$ & $0.478(0.088)$ & $0.435(0.101)$ & $0.444(0.089)$ \\
\hline
\end{tabular}

Source: See text.

$L=$ number of employees, $N=$ net P\&E, $K=$ R\&D capital; $N$ and $K$ are both measured at the beginning of the year. All variables except employment are deflated. A complete set of year dummies is included in each estimation. Numbers in parentheses are standard errors.

model in equation 7 of the body of the paper. The striking feature in this table is that unlike the sample as a whole, the R\&D capital in these firms regained its potency early in the 1980s after the decline in the 1970s and attained once again the rather high rate of return that it had in the 1960s. This sample is a very selected one-by and large it represents firms that thought $R \& D$ was an important enough signal to report it publicly even when they were not required to. Firms that desired secrecy for their R\&D spending are not in this sample; for example, IBM is not included. But the result is suggestive of a longerterm private payoff to $R \& D$ spending at the firm level. 


\section{Comments and Discussion}

Comment by Edwin Mansfield: Bronwyn Hall states that her principal results are of three kinds. First, the apparent decrease in the value of $R \& D$ relative to physical capital was composed of two effects, a fall in the absolute value of $R \& D$ assets and an increase in the value of ordinary capital as companies exited and the publicly traded manufacturing sector was reduced in size. Second, the decrease appeared to be concentrated in electrical equipment, instruments, computing, and electronics. Third, although the contribution of R\&D investment to productivity increase was low in the 1970s and the beginning of the 1980s, it seemed to pick up in the late 1980s except in the electrical, computing, machinery, metals, and auto industries.

Her paper emphasizes the size of a firm's R\&D expenditures as a determinant of the firm's valuation and productivity. In recent years many U.S. firms have tended to put more emphasis on using (as distinct from performing) R\&D. Given the well-publicized inability of some major U.S. firms to exploit their own R\&D, this tendency has been understandable, although it obviously can be carried too far. In addition, managements, stung by evidence that they have been slower and less effective than their Japanese (and other) rivals at exploiting external R\&D, have felt pressure to improve their performance in tapping the R\&D of other firms and organizations. Further, increased reliance has been put on cooperative R\&D and strategic alliances, which also have tended to reduce the significance of the size of individual firms' $R \& D$ expenditures.

Although some of these changes had been going on for some time, they seemed to accelerate during the middle and late 1980s, as man- 
agements put more and more emphasis on making R\&D more "efficient." Moreover, investors, like corporate managers, seemed to be influenced strongly by these changes in attitude. With so much attention devoted to cases where U.S. firms spent lots on R\&D that produced first-rate technical output exploited by other firms, many investors seemed to increase the emphasis they attached to how well a firm could use and exploit both its own R\&D and that of others, while decreasing the emphasis they attached to how much money it spent on R\&D. A good example was the attention devoted in the late 1980s to the robot industry, where the U.S. producers spent substantial amounts on R\&D, while the Japanese, building on earlier U.S. R\&D, were winning victories in the marketplace. ${ }^{1}$

Of course, there would be no reason on this account to reduce the emphasis attached to a firm's R\&D spending if a firm's ability to exploit internal and external R\&D were highly correlated with the size of its R\&D expenditures. But as the case of the U.S. and Japanese robot makers suggests, there is no convincing evidence (that I know of) that the size of a firm's R\&D spending is a dependable indicator of how much profit it obtains, per dollar of its own $R \& D$, from information and capabilities generated from its own and others' R\&D. This does not deny that a certain amount of R\&D is often necessary to allow a firm to imitate and build on externally generated technology as well as to use its own previous R\&D findings. But above this level, the correlation seems very imperfect. Many of the firms with the biggest R\&D budgets seem to have suffered at least as much as smaller R\&D spenders from inertia, lack of vision, and the not-invented-here syndrome.

Moreover, the level of spending on subsequent stages of the innovation process may be as important as $R \& D$ spending. The Japanese, for example, have devoted about 40 percent of the costs of developing and introducing a new product to tooling and manufacturing equipment and facilities, whereas U.S. firms have devoted only about 20 percent to those activities. ${ }^{2}$ Investors have come to realize that differences of this sort, which are not reflected in R\&D figures, may have at least as big an impact on the value of a firm as its R\&D spending. It was this spending on process engineering, not $R \& D$, that frequently was so

1. Mansfield (1989). See also Mansfield (1993).

2. Mansfield (1988). 
important to the success of Japanese producers. During the middle and late 1980 s, many reports, government and private, drove this point home.

A factor that clouds the picture during the 1980s is the R\&D tax credit, which Professor Hall cites in her paper. One disturbing effect of this credit, according to the available evidence, is that it resulted in some redefinition of activities as R\&D. This effect can be substantial. About ten years ago, I carried out and published a study financed by the National Science Foundation on the effects of the credit. Based on data obtained from the firms themselves, reported R\&D expenditures increased by about 4 percent a year for this reason alone. In Canada and Sweden, both of which had longer experience than the United States had with tax credits, my findings were quite similar. In both countries, firms said that reported company-financed $R \& D$ expenditures grew for this reason alone by about 13-14 percent over the three- or four-year period following the establishment of the credit. After the first few years, this redefinition process tends to stop, according to the firms. ${ }^{3}$

Note that much of this redefinition was simply breaking out and identifying R\&D that firms had no incentive to identify before; in addition, there seemed to be some relabeling of non-R\&D as $R \& D$, which the above figures are likely to underestimate. Even the Reagan administration, which was responsible for originating the credit, protested that " the imprecision of the current . . . definition has permitted taxpayers unwarranted flexibility in classifying business costs as R\&D expenditures."' And the Senate "concluded that the definition . . . allows taxpayers to claim the credit for virtually all preproduction expenses." 4

To my mind the evidence is strong enough to raise questions about the extent to which the apparent boom in R\&D spending during the early and middle 1980s was real. It is hard to believe that the increase in the R\&D-to-sales ratio in Professor Hall's figure 1 was not caused in part by this redefinition of activities. The extent to which this factor may have influenced her findings is very hard to say, but I think that the effect of this factor might be recognized more fully.

3. Mansfield (1985); Mansfield (1986).

4. Hearings before the House Ways and Means Subcommittee on Oversight, 98 Cong. 2 sess (Government Printing Office 1984), Statement of Ronald A. Pearlman, acting assistant secretary for tax policy, Department of the Treasury, pp. 34, 35. 
Her finding that the electronics industries have differed so substantially from the chemical and pharmaceutical industries is interesting and seems consistent with findings elsewhere that the latter industries have been more competitive (in terms of the speed and costs of innovation) with their foreign rivals than the former industries. ${ }^{5}$ These findings of hers show the benefits of disaggregation, and I agree with her that further disaggregation may be worthwhile. For example, the chemical sector includes petroleum and rubber, as well as chemicals. Because there are very significant differences among the three industries and because they differ considerably in R\&D intensity, the measured effects of R\&D may well include industry effects too.

Finally, I agree with Professor Hall's conclusion that the social returns from R\&D may have "diverged even more from the private returns in the 1980 s as the private returns dissipated more quickly, at least in some sectors." In many industries innovators face a large number of strong and capable potential rivals, and they enjoy shorter lead times over imitators. More and more emphasis is placed on cutting the time it takes to develop and introduce new products and processes. Just as American and European firms have rushed to use Japanese manufacturing methods, so they have tried to adapt Japanese development and commercialization strategies to their own conditions. One result seems to have been greater difficulties for innovators in appropriating the social benefits from their R\&D.

To sum up, I think Bronwyn Hall has written an interesting and useful paper and that she should be encouraged to probe further into the very important topics she has chosen to study. To understand central aspects of the economics of technological change and to forge sensible and effective technology policies, we need to know more about the economic impacts of R\&D.

Comment by Adam B. Jaffe: This paper presents two kinds of empirical evidence on the private returns to corporate R\&D in the 1980 s. It then discusses possible interpretations of the findings in the context of the changing competitive environment and the wave of corporate restructuring that took place. This is an important and timely topic. In January the Sloan Foundation and the Harvard Business School spon- 
sored a Conference on the Future of Industrial Research, at which academics and R\&D executives debated whether corporate downsizing means the end of industrial $R \& D$ as we know it and whether that would be a good thing or a bad thing if it happened. ${ }^{1}$ In a recent presidential address to the American Finance Association, Michael Jensen suggested that many large American firms spent huge amounts of money on R\&D (and investment) in the 1980s with very low returns and that this suggests a major failure of corporate control systems. ${ }^{2}$ And, of course, this hand-wringing about what is going on with corporate R\&D takes place against a backdrop of general concern about the competitiveness of U.S. industry. In this environment Hall performs an important service by thoroughly dissecting the basic facts with respect to two important indicators: market valuation and gross private returns.

With respect to market value, Hall performs yearly cross-sectional regressions, inferring the market's valuation of $R \& D$ assets from the cross-sectional partial correlation between value and reported R\&D. I think that this is an eminently sensible thing to do, but it is important to remember that it is inferring the market's valuation of $\mathrm{R} \& \mathrm{D}$, not really measuring it; anything that affects the firms' valuation that is left out of the regression and correlated with $R \& D$ will have its effects imputed to R\&D. It is also important to remember that the Compustat firms are a nonrepresentative sample of the manufacturing sector in two distinct ways. Large, established firms are overrepresented, and the small firms that are present are a peculiar sample, weighted toward the kind of high-technology firms that generate significant stock market interest. I will return to this issue below in the context of Hall's results that are size-weighted.

The basic findings are that, overall, R\&D did not join in the significant increase in valuation enjoyed by physical capital between 1982 and 1989. Indeed, figure 2 shows the inferred market valuation of R\&D declining by about 75 percent during this period. This is a stunning result. I come from Boston, where people moan endlessly about a 10 to 25 percent decline in real estate values since 1988 . If it were true that the aggregate value of the knowledge stock of the manufacturing

1. Simon (1993).

2. Jensen (1993) quotes (with approval) the Economist magazine as observing that "American industry went on an R\&D spending spree in the 1980s, with little to show for it." 
sector declined by 75 percent in less than a decade, this would be a capital loss of a magnitude for which I cannot think of a precedent.

Figure 3 demonstrates, however, that the story is much more complicated. The contrast between figure 3 and figure 2 is striking and provides a cautionary tale about the dangers of assuming that coefficients are constant across industries. The dramatic decline of figure 2 is confined to just two sectors: electrical and instruments, and computers and electronics. The other sectors show R\&D generally enjoying increases in valuation comparable to conventional capital. Thus, the puzzle is smaller than we thought. Hall's conjecture that the value of R\&D has been eroded in these sectors as increasing competition hastened obsolescence is plausible, although I doubt that it can account for a drop of the magnitude found here. I suspect that much of the decline in the relative valuation of $R \& D$-intensive firms has to do with variations in the market's view of subindustries.

The other major focus of the paper is the estimation of the elasticity of gross revenues with respect to R\&D by industry and for different periods. As Hall discusses, the assumption of a constant elasticity implies that rates of return (marginal products) for R\&D vary to the extent that firms have varying $R \& D$ intensities. Confining the analysis within industries, as Hall does, surely mitigates this problem but does not eliminate it. Even within industries, particularly broad sectors as defined here, there is a large variation in $R \& D$ intensity. I suspect that this underlying heterogeneity may be part of the reason why the elasticity results are so sensitive to issues of pooling and size-weighting. ${ }^{3}$

There are two levels on which to interpret table 3 . The first is to discern what happened, on average, to the gross private returns to $R \& D$ in these sectors during the last two decades. The other is to compare the top and bottom halves of the table to discern the differential success of large and small firms. Both efforts are frustrated to a significant degree by the general lack of systematic patterns. Whether one compares industries, time periods, or the weighted and unweighted results, no general patterns seem to emerge. Four out of the six industries have coefficients that are negative and significant for one of the last three time periods in one of the weighting schemes.

3. Bound and others (1984) found that in 1976 R\&D intensity tended to be highest for the very smallest and the very largest firms in the Compustat sample. This suggests that if the marginal product is constant, the $R \& D$ elasticity is highest for these firms. 
As I stare at these tea leaves, I conclude three things. R\&D is consistently productive in pharmaceuticals (which includes medical instruments in these data). Computer R\&D is more productive in small firms than in large. There is some evidence of a pickup in R\&D productivity in the second half of the 1980s, concentrated in chemicals and "other." 4 Beyond this, it is difficult to see much.

The suggestion about small firms is extremely interesting, given the broader debate about the relationship between $R \& D$ and corporate downsizing. I would be careful about pushing it too far, however. Over all sectors, there is as much evidence that size-weighting increases elasticity as there is that it decreases it. ${ }^{5}$ More fundamentally, I think that there is a problem in using these data to discern the differential performance of small and large firms. As noted above, the sample selection biases are different for the two groups. Small firms are much more likely to make it into the Compustat sample if they are high-tech success stories that generate investor interest. Large firms, by contrast, will be in the sample unless they are privately held.

Despite the ambiguity of the elasticity results, I think that Hall has performed a valuable service by putting these results in front of us. Academics all prefer to publish neat results that hang together and support their favorite hypotheses. There is too little published work that carefully lays out the stylized facts, with the puzzles and contradictions visible for all to see. I predict that other researchers will pick up where this paper leaves off and help us to understand these important issues.

General Discussion: Commenting on the author's argument that an increasing divergence between the private and social returns to $R \& D$ may explain why the rate of return to $R \& D$ remains high, while the stock market valuation of R\&D investment is low, Robert Hall argued that such a growing divergence would be at odds with recent develop-

4. There is some other evidence of recovering R\&D productivity in the late 1980 s. As Hall noted, the upswing in domestic patent applications and grants has been strong. Perhaps more telling, successful domestic corporate patent applications per dollar of private U.S. R\&D reversed its historic decline in 1986, and the ratio of U.S. patents granted to U.S. corporations over U.S. patents granted to foreign corporations reversed its long-term historical decline in 1988.

5. Size-weighting increases the coefficient for chemicals in 1986-90, and pharmaceuticals and machinery in 1981-85, while decreasing it for computers in both time periods and for miscellaneous in 1986-90. 
ments in property rights. Since the 1980 s, Hall said, enforcement of laws protecting trade secrets has increased, and patent owners have been very successful in protecting their intellectual property rights in court. Companies such as Texas Instruments now earn a large proportion of their total profits from licensing their patent rights, Hall added. Because these developments indicate the growing strength and importance of private property rights over the fruits of R\&D, Hall concluded, the author's hypothesis, if correct, would be paradoxical.

Zvi Griliches argued that new technologies in computers and communications have greatly reduced the costs of obtaining information. He suggested that this has made it cheaper for firms to find out information about new technological developments and newly issued patents and, as a result, may have reduced the rents accruing to private information. Although such a development is good from society's point of view, Griliches said, it has also resulted in significant depreciation of previously accumulated rents.

Ernst Berndt noted the developing body of literature that argues that computerization has had only marginal effects on productivity. He wondered to what extent R\&D-intensive industries are also computer-intensive ones and, accordingly, if the poor performances of R\&D investments and computer investments are linked. Frank Lichtenberg responded by pointing out that computers are used primarily in service industries, while most R\&D is performed within manufacturing, making it unlikely that the computerization paradox is connected to $R \& D$ investments.

Several participants offered suggestions on methodological and measurement issues. Ishaq Nadiri noted that the paper's first equation accounts only for the stock of old R\&D capital, not for the stock of old physical capital. He said that this asymmetrical treatment of the two types of capital affects the results and, consequently, that the author should review her specifications for this equation. Lichtenberg suggested that the author use detailed industry dummies in her equations, which, he argued, would make it unnecessary to be concerned with having the correct deflators. George Borts questioned the author's use of Tobin's $Q$ as the measure of market value of R\&D. He suggested that an alternate measure, excess returns in the stock market, would provide a better picture of market reaction to new R\&D expenditures. Looking at the author's specifications for her third equation, Frank 
Wolak argued that the only coefficient affected by assumptions about the $R \& D$ depreciation rate is that for the existing stock of $R \& D$, making it possible to estimate the relative valuation of new $R \& D$ without making any assumptions about the depreciation rate. Wolak also suggested using weights to control for the stratification of the sample in the Tobin's $Q$ regressions and to control for firm size in the sales regressions.

Several participants suggested areas of additional study. Henry Farber argued that the steep, steady decline in the return to new $R \& D$ investment shown in the results is less striking than the four points of very high return. He suggested that the author investigate these outliers more closely. Wolak argued that entering and exiting firms would most probably have different relative valuations of both new and old R\&D. Considering the large size of the data set used in the paper, he suggested breaking apart the sample to look at entrants and exiters, and he surmised that entrants would have greater $R \& D$ productivity.

Albert Link noted that cooperative $R \& D$ ventures have been growing in number since they were first made permissible by the National Cooperative Research Act of 1984. He argued that cooperative R\&D is often performed in a different venue from other $R \& D$ and, as a result, may be of a different character. He suggested that as cooperative R\&D increases in proportion to total $\mathrm{R} \& \mathrm{D}$, caution must be exercised in dealing with $R \& D$ data.

Michael Katz wondered whether firms have been overreporting their R\&D expenditures for tax purposes and, if they have, whether they have been exaggerating consistently. He noted that a Business Week survey of firms did not pick up the same increase in R\&D expenditures that these same firms had reported on their tax returns. He suggested that the author investigate this question by examining multiple sources and surveys providing $\mathrm{R} \& \mathrm{D}$ data.

Assuming that the paper includes telecommunications firms in the electrical and electronics sector, Linda Cohen argued that the deregulation of the telecommunications industry in the early 1980s, which resulted in a dramatic change in industry structure, may have had a noticeable effect on subsequent returns to new $R \& D$ in the electrical and electronics sector. She added that R\&D expenditures in telecommunications have not dropped since deregulation, although a change in the correlation between profits and R\&D spending has most probably occurred as expected. 


\section{References}

Allen, William T. 1992. "Corporate Directors in the Dawning Age of PostMangerialism." Stanford, Calif.: CEPR Conference on Corporate Governance, luncheon address.

Bhagat, Sanjai, Andrei Shleifer, and Robert W. Vishny. 1990. "Hostile Takeover in the 1980s: The Return to Corporate Specialization." Brookings Papers on Economic Activity: Microeconomics: 1990: 1-84.

Black, Bernard S. 1992. “Institutional Investors and Corporate Governance: The Case for Institutional Voice." Journal of Applied Corporate Finance (Fall 1992). 19-32.

. Forthcoming. "Next Steps in Corporate Governance Reform." In Lehn, Kenneth, and Robert Kamphuis, eds. Modernizing U.S. Securities Regulation: Economic and Legal Perspectives. Homewood, Ill.: Business One Irwin.

Blair, Margaret M., and Martha A. Schary. 1993. "Industry-Level Pressures to Restructure." In Blair, Margaret M., ed. The Deal Decade. Washington, D.C.: Brookings.

Bound, John, Clint Cummins, Zvi Griliches, Bronwyn H. Hall, and Adam B. Jaffe. 1984. "Who Does R\&D and Who Patents?' In Griliches, Zvi, ed. $R \& D$, Patents, and Productivity. Chicago: University of Chicago Press.

Bureau of Labor Statistics, U.S. Department of Labor. 1989. The Impact of $R \& D$ on Productivity Growth. Bulletin 2331. Washington, D.C.: GPO.

Business Week. 1992. Technology, R\&D, and Patents issue (July 13).

Caballero, Ricardo J., and Adam B. Jaffe. 1993. "How High are the Giants' Shoulders: An Assessment of Knowledge Spillovers and Creative Destruction in a Model of 'Economic Growth." Paper presented for NBER Macroeconomic Annual Meeting, March 14, Cambridge, Mass.

Chandler, A. D., Jr. Forthcoming. "Competitive Performance of U.S. Industrial Enterprises, A Historical Perspective 1880s-1980s." In Porter, Michael, ed. Capital Choices: Changing the Way America Invests in Industry. Boston: Harvard Business School Press.

Cockburn, Iain, and Zvi Griliches. 1988. "Industry Effects and Appropriability Measures in the Stock Market's Valuation of R\&D and Patents." American Economic Review 78 (May): 419-23.

Council of Economic Advisers. 1993. Economic Report of the President. Washington, D.C.: GPO.

Cuneo, Philippe, and Jacques Mairesse. 1984. "Productivity and R\&D at the Firm Level in French Manufacturing.' In Griliches, Zvi, ed. $R \& D$, Patents, and Productivity. Chicago: University of Chicago Press.

Griliches, Zvi. 1979. "Issues in Assessing the Contribution of Research and 
Development to Productivity Growth.' Bell Journal of Economics 10 (Spring): 92-116.

. 1980a. "R\&D and the Productivity Slowdown." American Economic Review 70 (May): 343-48.

. 1980b. "Returns to Research and Development Expenditures in the Private Sector." In Kendrick, John W., and Beatrice N. Vaccara, eds., New Developments in Productivity Measurement and Analysis. Chicago: University of Chicago Press.

. 1981. "Market Value, R\&D, and Patents." Economic Letters 7: $1983-1987$.

. 1986. "Productivity, R\&D, and Basic Research at the Firm Level in the 1970s." American Economic Review 76 (March): 141-54.

. 1989. "Patents: Recent Trends, and Puzzles." Brookings Papers on Economic Activity: Microeconomics: 1989: 291-319.

Griliches, Zvi, and Jerry A. Hausman. 1986. "Errors in Variables in Panel Data." Journal of Econometrics 31 (February): 93-118.

Griliches, Zvi, and Jacques Mairesse. 1983. "Comparing Productivity Growth: An Exploration of French and U.S. Industrial and Firm Data." European Economic Review 21 (March/April): 89-119.

1984. "Productivity and R\&D at the Firm Level." In Griliches, Zvi, ed. $R \& D$, Patents, and Productivity. Chicago, Illinois: University of Chicago Press.

Grundfest, Joseph A. 1993. "Just Vote No: Minimalist Strategies for Dealing with Barbarians inside the Gates." Stanford Law Review 45 (April): 857937.

Hall, Bronwyn H. 1990. “The Manufacturing Sector Master File: 19591987.' Working Paper 3366. Cambridge, Mass.: National Bureau of Economic Research.

_. 1991. "Corporate Restructuring and Investment Horizons." Working Paper No. 3794. Cambridge, Mass.: National Bureau of Economic Research.

1992. "Investment and Research and Development at the Firm Level: Does the Source of Financing Matter?' Working Paper 4096. Cambridge, Mass.: National Bureau of Economic Research.

1993a. “R\&D Tax Policy during the 1980s: Success or Failure?' Tax Policy and the Economy 7: 1-36.

- 1993b. "The Stock Market Value of R\&D Investment during the 1980s." American Economic Review 83 (May): 259-64.

. 1993c. "The Value of Intangible Corporate Assets: An Empirical Study of the Components of Tobin's Q."' Working Paper 93-207. University of California, Berkeley.

Hall, Bronwyn H., Clint Cummins, Elizabeth S. Laderman, and Joy Mundy. 
1988. “The R\&D Master File Documentation." Technical Working Paper

72. Cambridge, Mass.: National Bureau of Economic Research.

Hall, Bronwyn H., and Fumio Hayashi. 1988. "Research and Development as an Investment.' Working Paper 2973. Cambridge, Mass.: National Bureau of Economic Research.

Hall, Bronwyn H., and Jacques Mairesse. Forthcoming. "Exploring the Relationship between R\&D and Productivity in French Manufacturing Firms." Journal of Econometrics.

Hall, Bronwyn, H., and Robert E. Hall. 1993. "The Value and Performance of U.S. Corporations."' Brookings Papers on Economic Activity: 1993 (1): $1-50$.

Hall, Bronwyn H., Zvi Griliches, and Jerry A. Hausman. 1986. "Patents and R\&D: Is There a Lag?' International Economic Review 27 (June): 265-83.

Hayashi, Fumio. 1982. “Tobin's Marginal $Q$ and Average $Q$ : A Neoclassical Interpretation." Econometrica 50 (January): 213-24.

Hayashi, Fumio, and T. Inoue. 1991. “The Relation between Firm Growth and $Q$ with Multiple Capital Goods: Theory and Evidence from Panel Data on Japanese Firms." Econometrica 59 (May): 731-54.

Himmelberg, Charles P., and Bruce C. Petersen. 1991. "R\&D and Internal Finance: A Panel Study of Small Firms in High-Tech Industries." Working Paper WP-91-25. Federal Reserve Bank of Chicago.

Jensen, Michael. 1991. "Corporate Control and the Politics of Finance." Journal of Applied Corporate Finance 4 (Summer): 13-33.

1993. "The Modern Industrial Revolution, Exit, and the Failure of Internal Control Systems." Journal of Finance 48 (July): 831-80.

Lichtenberg, Frank R., and Donald Siegel. 1990. “The Effects of Leveraged Buyouts on Productivity and Related Aspects of Firm Behavior.' Journal of Financial Economics 27 (September): 1-30.

. 1991. "The Impact of R\&D Investment on Productivity-New Evidence Using Linked R\&D-LRD Data." Economic Inquiry 29 (April): 20328.

Mairesse, Jacques, and Bronwyn H. Hall. 1993. "R\&D Investment and Productivity Growth in the 1980s: A First Look at the United States and French Manufacturing Sectors." Paper presented at the American Economic Association Meeting, Anaheim, Calif. Jan. 5-7, 1993.

Mairesse, Jacques, and Mohamed Sassenou. 1991. "R\&D and Productivity: A Survey of Econometric Studies at the Firm Level.' Science-TechnologyIndustry Review 8:317-48.

Mansfield, Edwin. 1985. "Public Policy toward Industrial Innovation: An International Study of Direct Tax Incentives for R\&D." In Clark, Kim, Robert Hayes, and Christopher Lorenz, eds. The Uneasy Alliance: Managing the Productivity-Technology Dilemma. Boston: Harvard Business School. 
- 1986. "The R\&D Tax Credit and Other Technology Policy Issues." American Economic Review 76 (May): 190-94.

1988. “Industrial Innovation in Japan and the United States." Science 241 (September 30): 1769-74.

. 1989. "The Diffusion of Industrial Robots in Japan and the United States."' Research Policy 18 (August;): 83-92.

- 1993. "The Diffusion of Flexible Manufacturing Systems, in Japan, Europe, and the United States.' Management Science 39 (February): 14959.

Nadiri, M. Ishaq, and George C. Bitros. 1980. "Research and Development Expenditures and Labor Productivity at the Firm Level: A Dynamic Model.", In Kendrick, John W., and Beatrice N. Vaccara, eds. New Developments in Productivity Measurement and Analysis. Chicago: University of Chicago Press.

National Science Foundation. 1985. Science Indicators 1985. Washington, D.C.: GPO. GPO.

Schankerman, Mark. 1981. "The Effects of Double Counting and Expensing on the Measured Returns to R\&D." Review of Economics and Statistics 63 (August): 454-58.

Simon, John. 1993. "The R\&D Dilemma: The High Cost of Cutting Back." Harvard Business School Bulletin. 69 (April): 34-39.

Standard and Poor Corporation. 1991 and earlier editions. The Compustat Annual Industrial and OTC Files. New York: Standard and Poor. Datatapes. 